\title{
8. SITE 378: CRETAN BASIN
}

\author{
Shipboard Scientific Party ${ }^{1}$
}

\section{SITE DATA}

\section{Position:}

Hole $378: 35^{\circ} 55.67^{\prime} \mathrm{N}, 25^{\circ} 06.97^{\prime} \mathrm{E}$

Hole $378 \mathrm{~A}: 35^{\circ} 55.67^{\prime} \mathrm{N}, 25^{\circ} 06.97^{\prime} \mathrm{E}$

Water Depth (sea level):

Hole 378: 1835 corrected meters, echo sounding

Hole 378A: 1835 corrected meters, echo sounding

Bottom Felt at: 1845 meters, drill pipe

Penetration:

Hole 378: 312.0 meters

Hole 378A: 343.5 meters

Number of Holes: 2

Number of Cores:

Hole 378: 11

Hole 378A: 9

Total Core Recovered:

Hole 378: 34.8 meters

Hole 378A: 20.0 meters

Percentage Core Recovery:

Hole $378: 34.7 \%$

Hole 378A: $43.5 \%$

Oldest Sediment Cored

Depth subbottom:

Hole 378: 312 meters

Hole 378A: 343.5 meters

Nature:

Hole 378: Marlstone

Hole 378A: Gypsum

Age:

Hole 378: Early Pliocene

Hole 378A: Late Miocene

Basement: Not reached

Principal Results: Site 378 (Holes 378 and 378A) was located in the north Cretan Basin (Figure 1). Its maximum penetration was 343.5 meters with termination in

${ }^{1}$ Kenneth J. Hsü (Co-chief scientist), Eidg. Technisches Hochschule, Geologisches Institut, Zurich, Switzerland; Lucien Montadert (Co-chief scientist), Division Geologie, Institut Francais du Petrole, Rueil Malmaison, France; Daniel Bernoulli, Geologisch-palaontologisches Institut der Universitat Basel, Basel, Switzerland; Germaine Bizon, Bureau d'Etudes Industrielles et de Cooperation de l'Institut Francais du Petrole, Rueil Malmaison, France; Maria Cita, Instituto di Geologia, Universita degli Studi di Milano, Milano, Italy; Al Erickson, Department of Geology, University of Georgia, Athens, Georgia; Frank Fabricius, Institut fur Geologie Techn. Universitat, Munich, Germany; Robert E. Garrison, University of California, Santa Cruz, California; Robert B. Kidd, Institute of Oceanographic Sciences, Wormley, United Kingdom; Frederic Mélières, Laboratoire de Geologie Dynamique, University of Paris, Paris, France; Carla Müller, Geologisch-Paleontologisches Instutut der Johann Wolfgang Geothe-Universitat, Frankfurt, Germany (Present address: Bureau d'Etudes Industrielles et de Cooperation de L'Institut Francais du Petrole, Rueil Malmaison, France); Ramil C. Wright, Beloit College, Department of Geology, Beloit, Wisconsin (Present address: Department of Geology, The Florida State University, Tallahassee, Florida.

\begin{abstract}
Messinian gypsum. Its objectives were to investigate the close of evaporite deposition, the paleooceanography of the Plio-Quaternary, and the age of the last deformation of this marginal basin. The Quaternary sequence of nannofossil marls and ooze with numerous sapropels and sapropelic layers was deposited at a high sedimentation rate (up to $200 \mathrm{~m} / \mathrm{m}$.y.). The more compacted and slightly cemented Pliocene nannofossil marlstones contained numerous sapropels and burrows. The Plio-Pleistocene sapropels and sapropelic layers display numerous burrows and current structures. At the base of the Pliocene sequence, the sedimentation rate decreases sharply to about $9 \mathrm{~m} / \mathrm{m} . \mathrm{y}$. The late Miocene evaporites are represented mainly by coarse selenitic overlain by a brecciated dolomitic gypsum limestone. These are interpreted as having been deposited in a shallow subaqueous environment with occasional subaerial diagenesis. The "Lago Mare" facies of dolomitic marls, which was found at the other eastern Mediterranean sites, is absent here. The most recent major deformation event in the Cretan Basin was probably in the early to middle Quaternary. Heat-flow studies support geophysical interpretations of the area as a recently created back-arc basin, which is presently being underthrust by the eastern Mediterranean sea floor.
\end{abstract}

\section{BACKGROUND AND OBJECTIVES}

\section{Background}

The Aegean Sea (Figure 2) includes a number of inter-connected basins, most of them less than 2000 meters deep. The main basins are as follows: the Cretan Basin, in a back-arc setting of late Neogene age; the Central Aegean Basin, where a number of islands belonging to discrete structural units are present; the Northern Aegean Basin, striking westsouthwest to east-northeast which has been interpreted as a rifted basin (McKenzie, 1972) developed along the North Anatolian Fault which is also of probable late Neogene age. No deep submarine holes have been drilled in the Aegean Sea, with the exception of offshore oil exploration wells in the Northern Aegean Basin near the island of Thasos where upper Miocene evaporites have been encountered.

Because of the complex geological setting of the area, a deep penetration site was not expected to produce information of more than local significance to the understanding of the pre-Messinian history of the Mediterranean, and a major time commitment at this site was not foreseen. Notwithstanding this limitation, the Mediterranean Advisory Panel believed the proposed drill site to be a suitable location to test models of evaporite genesis, that had been proposed following the 1970 deep-sea drilling cruise and, in addition, to provide a calibration for the interpretation of existing seismic profiles. 

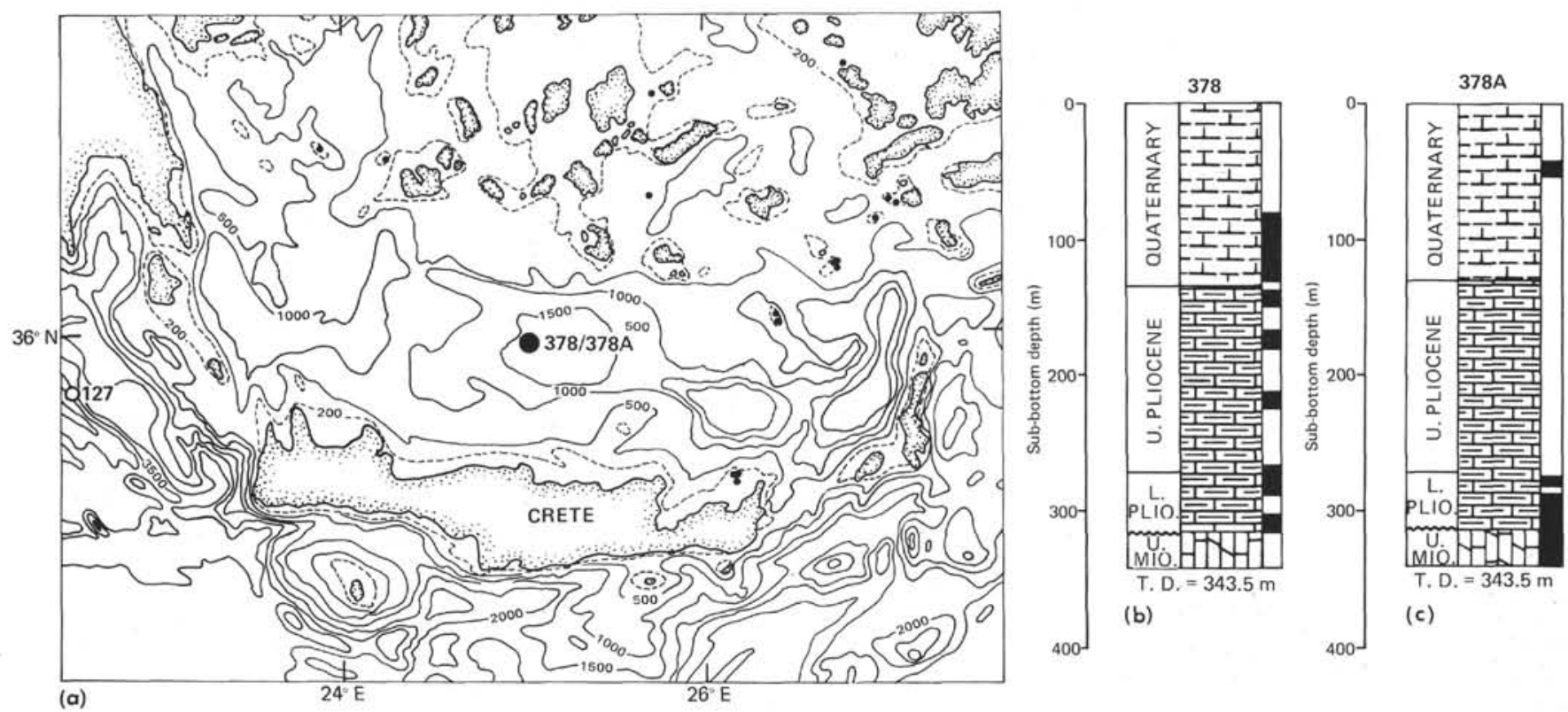

(c)

Figure 1. (a) Site location map (depth contours in meters); (b) generalized hole summary: Hole 378; and (c) generalized hole summary: Hole $378 \mathrm{~A}$.

\section{Objectives}

The original proposals for drilling in the Aegean Sea suggested that drilling here could:

1) date the end of evaporite deposition and study its environmental significance;

2) investigate the nature of the Pliocene transgression; whether this was by flooding of a previously desiccated or restricted deep basin, or by progressive shore-line transgression of a subsiding shallow basin;

3) determine the age of the earliest stagnant cycle after the Pliocene transgression;

4) investigate the relationship of sapropel sedimentation in the Pleistocene to eustatic sea level changes and specifically the interaction of the Black Sea with the eastern Mediterranean;

5) compare the sedimentary sequence in the Cre$\tan$ Basin with back-arc basins in the Pacific, and with volcanogenic sequences in ancient geosynclines; and

6) obtain a heat-flow value for the Aegean Sea.

The proposed site was located on BGR/Meteor 33 Profile 13, which crossed the Cretan Basin from north to south. The profile suggested the presence of three seismic units (Figure 3 ): (1) ponded sediments (mainly turbidites), (2) hemipelagic sediments, and (3) evaporites.

We decided to shift the originally proposed site slightly north to around $35^{\circ} 56^{\prime} \mathrm{N}$ and $25^{\circ} 07^{\prime} \mathrm{E}$, at about 1800 meters depth, in order to avoid the probable presence there of turbidites in the ponded facies.

Our specific objectives at Site 378 were:

1) to determine the stratigraphy of the ponded sediments and hence the evolution of Neogene tectonic movements of the region;

2) to determine the age and origin of the discontinuities in the seismic record; and
3) to sample and date the "acoustic basement," which according to the Meteor 33 refraction seismic measurements had a sonic velocity of $6.0 \mathrm{~km} / \mathrm{sec}$.

\section{OPERATIONS}

\section{Site Approach}

Glomar Challenger approached the site from the west on the afternoon of 17 May, cruising at 9.4 knots on a heading of $086^{\circ}$. Its course was set by computer to arrive at a predetermined turning point at 1615 LCT, after the 1606 LCT satellite fix was completed (Figure 4). The vessel turned to port at 1615 LCT and was on course by $1621 \mathrm{LCT}$ heading $356^{\circ}$. We could then follow the BGR/"Meteor" 33 Profile 13 northward. A minor adjustment of the heading to $010^{\circ}$ was made at 1629 LCT and speed was reduced to 6 knots at $1655 \mathrm{LCT}$. The vessel passed over the target site at 1641 LCT, when the beacon was dropped. Immediately afterwards the seismic gear was retrieved and the vessel made a Williamson turn to return to the station. She was homed on the beacon at 1730 LCT at $35^{\circ} 55.67 \mathrm{~N}, 25^{\circ} 06.91^{\prime} \mathrm{E}$. The PDR indicated a water depth of 966 fathoms (uncorrected) or 1851 meters (corrected to rig floor).

\section{Operations}

The drilling crew began to assemble the drill string as soon as the vessel was on location. At 2100 LCT 17 May, the string touched the seabed at 1845 meters depth, and 84 meters were washed down before the first core was taken. The sediment in Core 1 was early Quaternary in age and hemipelagic, suggesting that the bit had already penetrated beyond the contact between the ponded and the hemipelagic facies. A continuous coring schedule was followed until 131.5 meters sub- 


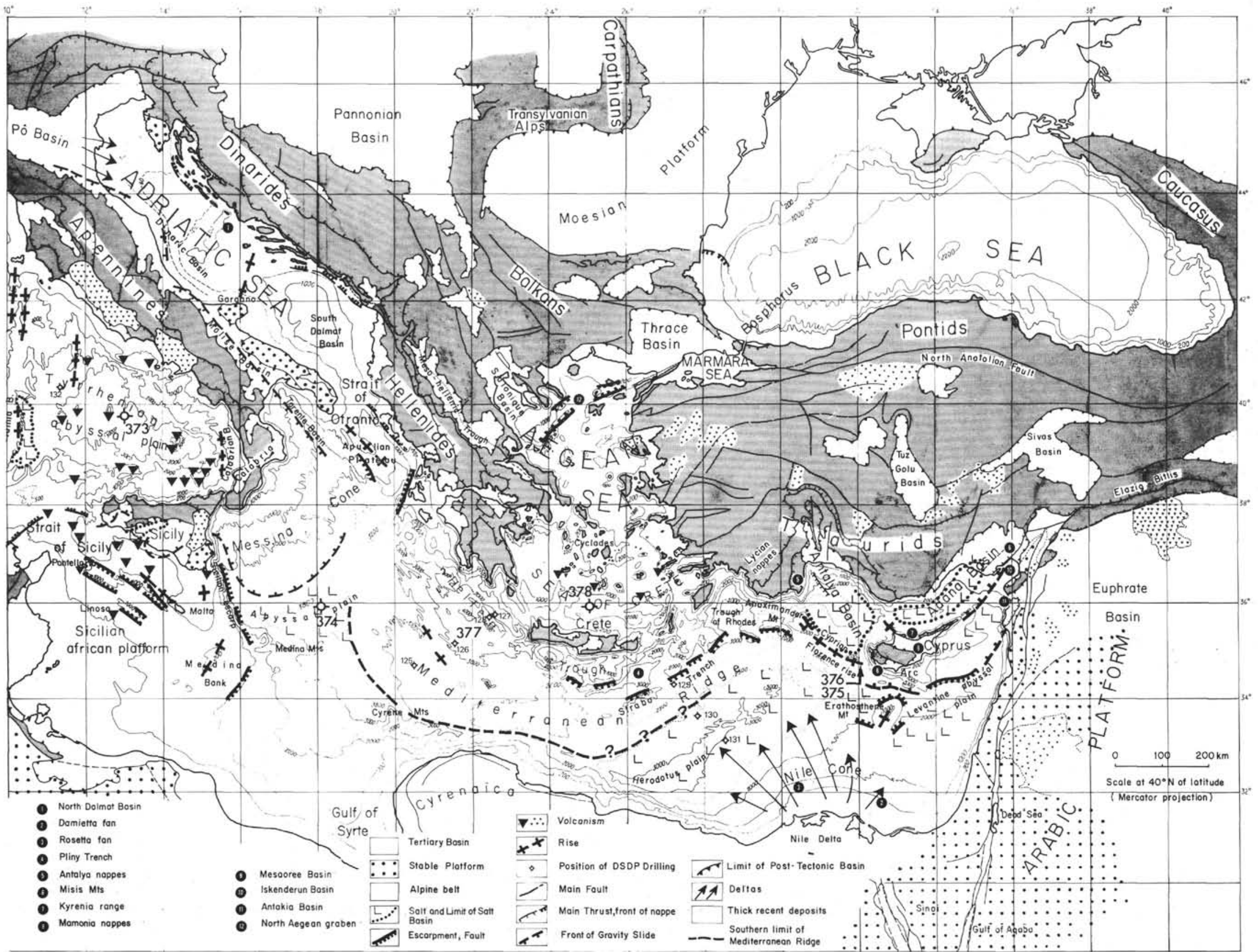



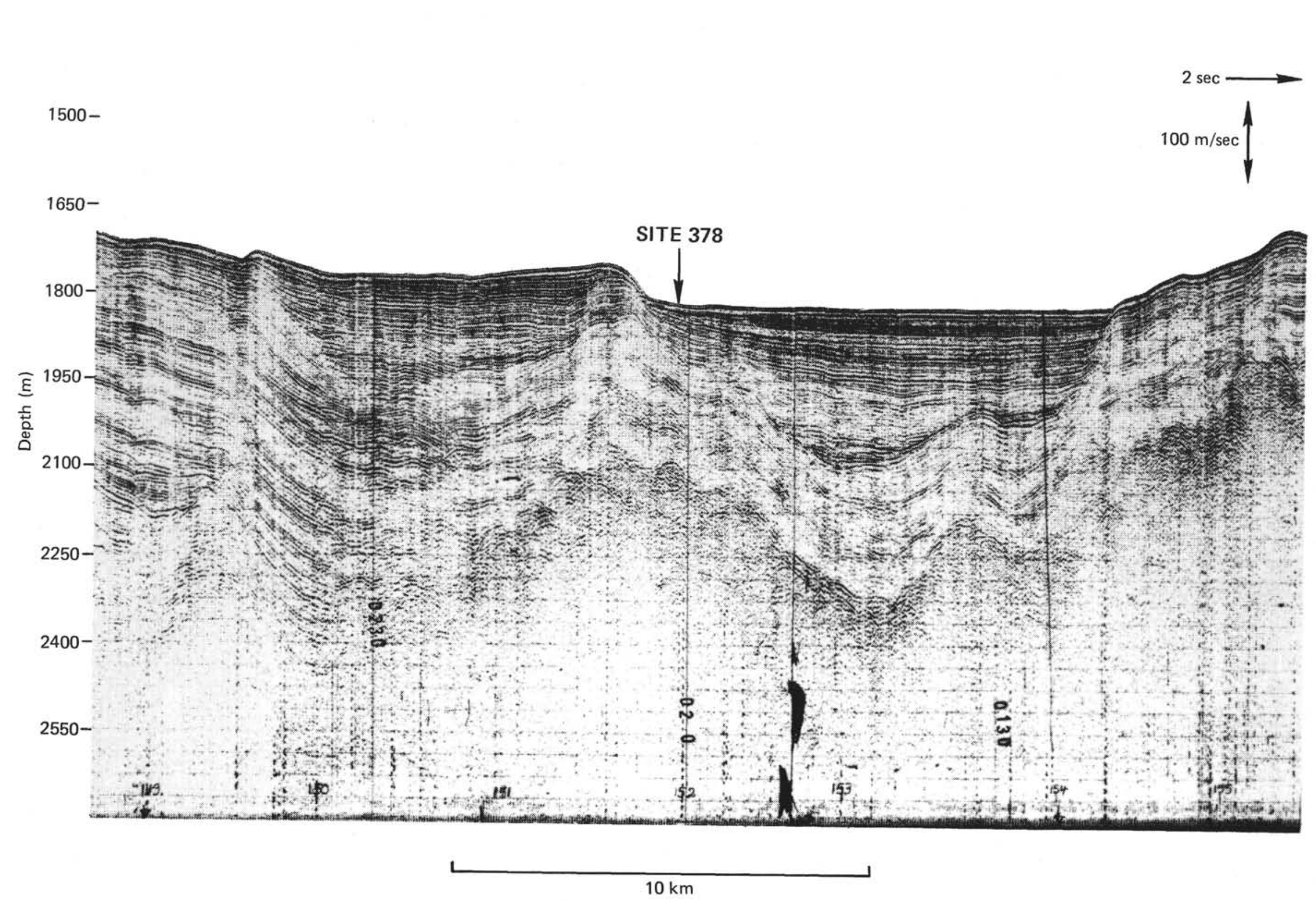

Figure 3. Position of Site 378 on BGR/'Meteor' 33 profile 13. 


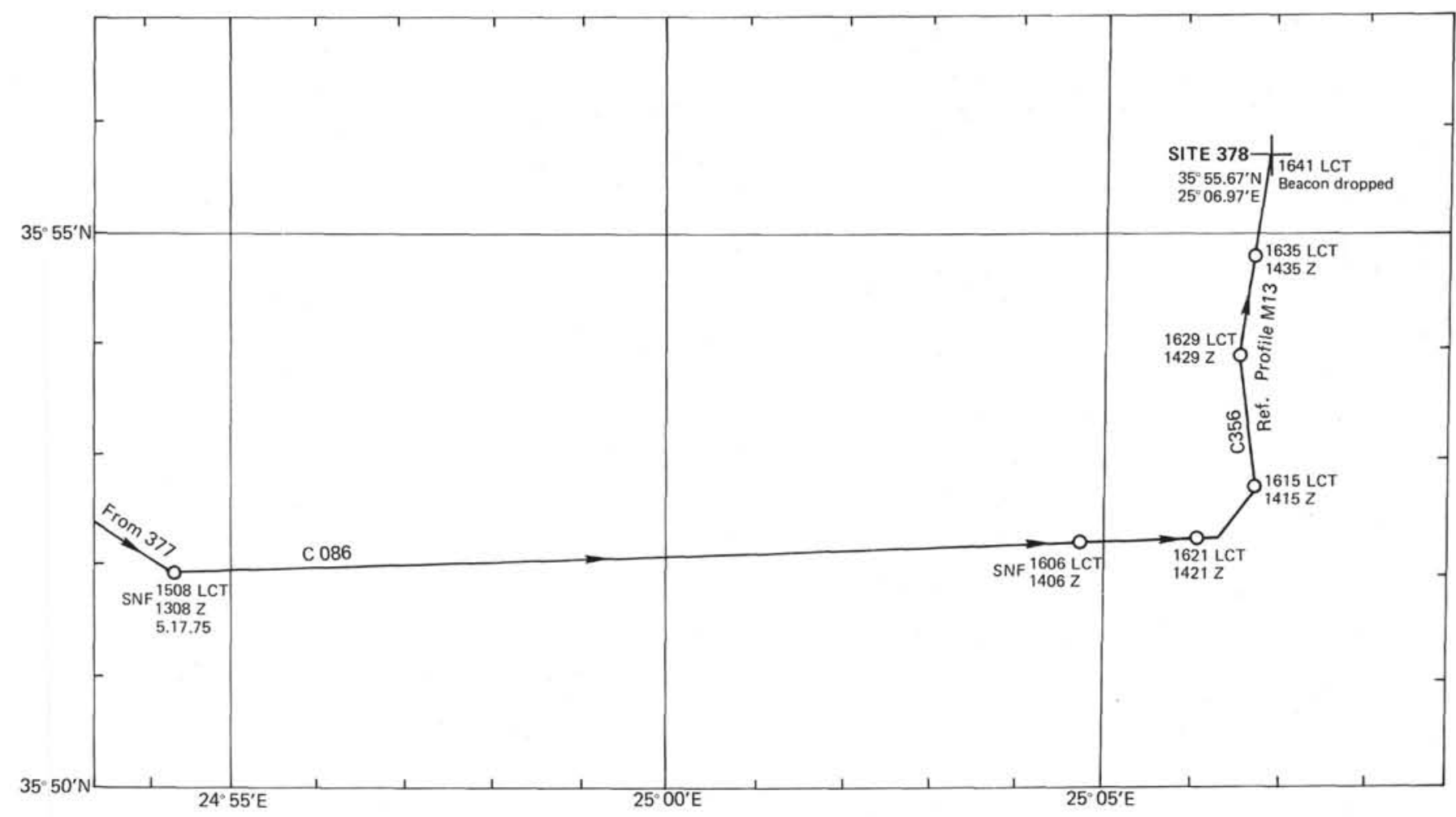

Figure 4. Site approach: Site 378.

bottom. When Core 5 was raised, its sediment still indicated an early Quaternary age and it was decided to spot core. The first heat-flow measurement had been made at 122 meters and a second was completed at 226 meters subbottom. (Details of all heat-flow operations and results appear in Erickson and Von Herzen, this volume).

At 0700 LCT the core barrel with heat-flow instrument attached was raised on deck, but the heat-flow probe had been lost in the hole. There was some concern that the probe would prevent the seating of the next core barrel. Fortunately, the barrel was properly seated at 0103 LCT and 47.5 meters were drilled before Core 9 was cut. When the next barrel was raised on deck, it was found to contain some marls in the core catcher and the lost heat probe in the plastic liner. Since it was uncertain whether Core 9 was obtained from the top $(-227 \mathrm{~m})$ or the bottom $(-283 \mathrm{~m})$ of the drilled interval, it was decided to take a core immediately afterwards at 283.5 meters subbottom. When the next core (Core 10) was brought up, it was again empty. Only traces of marl and sapropel were found between the teeth of the core catcher. A study of the catcher indicated that the marl was so sticky that the core barrel was pulled out without the cored sediment. The teeth of the catcher had been bent outward but did not close, so that the sediment was left behind. The core-catcher sediment was dated as Pliocene, on the basis of its nannofossil content. Twenty meters had been drilled ahead before the need to core continuously was recognized from a faunal analysis of the foraminifers. At about the same time, the needle on the weight indicator began to bounce suggesting that the Aegean M-reflector had been encountered at 317 meters subbottom. A core was cut and was raised on deck at 0955 LCT. The core contained Pliocene ooze, and a few pieces of caliche-like limestone.

Meanwhile, after some discussion, it was decided that a second hole should be drilled at the same site to fulfill some of the objectives missed prior to encountering the M-reflector. An order to terminate Hole 378 was given as soon as the presence of limestone was ascertained (see Table 1).

At 1015 LCT the drilling crew began to retrieve the drill string. At 1100 LCT 18 May, the drill string was above the mudline; it was offset and Hole 378A was spudded in. A core (378A-1) was taken between 46.0 and 55.5 meters subbottom to more accurately date the change in sedimentation from the hemipelagic to the ponded facies. The procedure was then to wash down to between 280.5 and 290 meters subbottom, an interval which would be more or less equivalent to Core 10 of Hole 378. When this interval was cored and raised, it was found to be almost empty, except for traces of sediment lodged in the teeth of the core catcher, exactly as in Core 378-10. The hole was then cleaned up as far as -293 meters, by circulating mud for a heat-flow measurement. After a further core, which sampled the Pliocene, the interval was reached just above the reflector. The $\mathrm{M}$-reflector was again encountered at 317 meters subbottom. However, here Core 4 which had 1.5 meters recovery, contained mainly selenitic gypsum. (A discussion on the Pliocene-Miocene contact follows below.) 
TABLE 1

Hole 378, Coring Summary

\begin{tabular}{|c|c|c|c|c|c|c|c|}
\hline Core & $\begin{array}{l}\text { Date } \\
\text { (May } \\
1975 \text { ) }\end{array}$ & Time & $\begin{array}{l}\text { Depth From } \\
\text { Drill Floor } \\
(\mathrm{m})\end{array}$ & $\begin{array}{l}\text { Depth Below } \\
\text { Sea Floor } \\
(\mathrm{m})\end{array}$ & $\begin{array}{c}\text { Cored } \\
\text { (m) }\end{array}$ & $\begin{array}{l}\text { Recovered } \\
\text { (m) }\end{array}$ & $\begin{array}{c}\text { Recovery } \\
(\%)\end{array}$ \\
\hline 1 & 17 & 2235 & $1929.0-1938.5$ & $84.0-93.5$ & 9.5 & 2.3 & 24 \\
\hline 2 & 17 & 2315 & $1938.5-1948.0$ & $93.5-103.0$ & 9.5 & 6.3 & 66 \\
\hline 3 & 18 & 00.0 & $1948.0-1957.5$ & $103.0-112.5$ & 9.5 & 4.2 & 44 \\
\hline 4 & 18 & 0112 & $1957.5-1967.0$ & $112.5-122.0$ & 9.5 & 0.1 & 1 \\
\hline 5 & 18 & 0310 & $1967.0-1976.5$ & $122.0-131.5$ & 9.5 & 3.0 & 32 \\
\hline 6 & 18 & 0400 & $1986.0-1995.5$ & $141.0-150.5$ & 9.5 & 3.3 & 35 \\
\hline 7 & 18 & 0455 & $2014.5-2024.0$ & $169.5-179.0$ & 9.5 & 7.2 & 76 \\
\hline 8 & 18 & 0600 & $2062.0-2071.5$ & $217.0-226.5$ & 9.5 & 3.2 & 34 \\
\hline 9 & 18 & 0745 & $2119.0-2128.5$ & $274.0-283.5$ & 9.5 & 0.1 & 1 \\
\hline 10 & 18 & 0855 & $2128.5-2138.0$ & $283.5-292.0$ & 9.5 & 0.1 & 1 \\
\hline 11 & 18 & 0955 & $2152.5-2157.0$ & $302.5-312.0$ & 9.5 & 4.7 & 49 \\
\hline Total & & & & & 104.5 & 39.5 & 38 \\
\hline
\end{tabular}

TABLE 2

Hole 378A, Coring Summary

\begin{tabular}{|c|c|c|c|c|c|c|c|}
\hline Core & $\begin{array}{l}\text { Date } \\
\text { (May } \\
1975 \text { ) }\end{array}$ & Time & $\begin{array}{l}\text { Depth From } \\
\text { Drill Floor } \\
\text { (m) }\end{array}$ & $\begin{array}{l}\text { Depth Below } \\
\text { Sea Floor } \\
\text { (m) }\end{array}$ & $\begin{array}{c}\text { Cored } \\
(\mathrm{m})\end{array}$ & $\begin{array}{l}\text { Recovered } \\
\text { (m) }\end{array}$ & $\begin{array}{c}\text { Recovery } \\
\text { (\%) }\end{array}$ \\
\hline 1 & 18 & 1205 & $1891.0-1900.5$ & $46.0-55.5$ & 9.5 & 7.2 & 76 \\
\hline 2 & 18 & 1530 & $2125.5-2135.0$ & $280.5-290.0$ & 9.5 & 0.1 & 1 \\
\hline 3 & 18 & 1655 & $2138.0-2147.5$ & $293.0-302.5$ & 9.5 & 9.5 & 100 \\
\hline 4 & 18 & 1855 & $2147.5-2157.0$ & $302.5-312.0$ & 9.5 & 1.5 & 16 \\
\hline 5 & 18 & 2050 & $2165.0-2166.5$ & $320.0-321.5$ & 1.5 & 1.0 & 67 \\
\hline 6 & 18 & 2230 & $2175.0-2176.0$ & $330.0-331.0$ & 1.0 & 1.0 & 100 \\
\hline 7 & 19 & 0015 & $2182.5-2185.5$ & $337.5-340.5$ & 3.0 & 0.0 & 0 \\
\hline 8 & 19 & 0100 & $2185.5-2187.5$ & $340.5-342.5$ & 2.0 & Trace & 0 \\
\hline 9 & 19 & 0220 & $2187.5-2188.5$ & $342.5-343.5$ & 1.0 & 0.0 & 0 \\
\hline Total & & & & & 46.5 & 20.3 & 44 \\
\hline
\end{tabular}

Cores 5 and 6 of Hole 378A also contained selenitic gypsum. The last three cores recovered nothing other than pieces of selenitic crystals and fine-grained bedded gypsum. It was thought that we might have encountered a halite section, and to minimize solution the last core was cut with drilling mud. At 0220 LCT the barrel, containing a carefully cut 1-meter core, was brought on deck. Again it was empty. A small sample of water which had leaked out of the core barrel was analyzed and it was found to be nominally saline. Since the time allotted for drilling and coring was now complete, the crew began to retrieve the drill string. They completed their task at 0652 LCT 19 May (see Table 2).

After the drill bit was brought on deck, it was found that the roller cones had completely collapsed, and the orifice between the three cones was almost closed. No sediment could have entered the barrel except for the chips of selenite and bedded gypsum found in the core catcher of Core 8.

At 0700 LCT, all drilling and coring operations were complete for Leg $42 \mathrm{~A}$ and the vessel departed for Istanbul.

\section{The Pliocene-Messinian Contact at Site 378}

A major change in lithology was encountered at 307 meters subbottom in both Holes 378 and 378A. Cores 378-11 and 378A-4 cored exactly the same interval
(302.5 to $312.0 \mathrm{~m}$ subbottom) with 4.7 meters and 1.5 meters recovery, respectively. However, the two cores contained very different sediments. Core $378-11$ is mainly a Pliocene ooze with a few chips of carbonate rock in the core catcher. Core $378 \mathrm{~A}-4$ is mainly massive selenite with a thin layer of Pliocene marl ooze at the top.

The stratigraphic interpretation suggested is: Pliocene marl ooze $=302.5$ to 307 meters Carbonate rock $=307$ to $308( \pm 1)$ meters Gypsum (selenite) $=308( \pm 1)$ to 312 meters The placing of the carbonate rock interval above the gypsum is based upon observation of the action of the bit weight indicator which was not agitated so extremely when the reflector was first encountered. A similar interpretation is suggested by observations of the drilling rates.

\section{LITHOLOGY}

Four lithologic units are recognized at Site 378 based on the discontinuous coring in Holes 378 and 378A. The upper three are hemipelagic calcareous units, all rich in nannofossils, and with drab colors. They are distinguished from one another by differences in age, physical coherence, and types and degree of burrowing. Unit 2, the basal unit, is gypsum. Holes 378 and $378 \mathrm{~A}$ are considered together in establishing this lithologic sequence (see Table 3 ). 
TABLE 3

Lithologies at Site 378

\begin{tabular}{|c|c|c|c|c|c|c|c|}
\hline \multirow[b]{2}{*}{ Unit } & \multirow{2}{*}{\multicolumn{2}{|c|}{ Lithology }} & \multicolumn{2}{|c|}{ Cores } & \multirow{2}{*}{$\begin{array}{l}\text { Sub-bottom } \\
\text { Depth } \\
\text { (m) }\end{array}$} & \multirow{2}{*}{$\begin{array}{l}\text { Estimated } \\
\text { Thickness } \\
\text { (m) }\end{array}$} & \multirow[b]{2}{*}{ Age } \\
\hline & & & $\begin{array}{r}\text { Hole } \\
378\end{array}$ & $\begin{array}{l}\text { Hole } \\
378 \mathrm{~A}\end{array}$ & & & \\
\hline \multirow[t]{2}{*}{ I } & (a) & $\begin{array}{l}\text { Nannofossil marl } \\
\text { with interlayers of } \\
\text { sapropelic marl } \\
\text { and marl con- } \\
\text { glomerate }\end{array}$ & & 1 & $0-64$ & 64 & Quaternary \\
\hline & (b) & $\begin{array}{l}\text { Nannofossil marl } \\
\text { and ooze with } \\
\text { sapropelic marl } \\
\text { interlayers }\end{array}$ & $1-5$ & & $64-131.5$ & 67.5 & Quaternary \\
\hline II & $\begin{array}{l}\text { Nan } \\
\text { wit1 } \\
\text { sapr }\end{array}$ & $\begin{array}{l}\text { nnofossil marlstone } \\
\mathrm{h} \text { interlayered } \\
\text { ropelic marlstone }\end{array}$ & $6-10$ & & $131.5-286$ & 154.5 & $\begin{array}{l}\text { Late } \\
\text { Pliocene }\end{array}$ \\
\hline III & $\begin{array}{l}\text { Nan } \\
\text { witl } \\
\text { row } \\
\text { sapr } \\
\text { inte }\end{array}$ & $\begin{array}{l}\text { anofossil marlstone } \\
\text { h abundant bur- } \\
\text { vs and numerous } \\
\text { ropelic marlstone } \\
\text { erlayers }\end{array}$ & 11 & 3 & $286-308$ & 22 & $\begin{array}{l}\text { Early } \\
\text { Pliocene }\end{array}$ \\
\hline IV & $\begin{array}{l}\text { Sele } \\
\text { min } \\
\text { bre }\end{array}$ & $\begin{array}{l}\text { enitic gypsum with } \\
\text { tor limestone } \\
\text { ccia }\end{array}$ & $11, \mathrm{CC}$ & $\begin{array}{l}(6-2) \\
4-6\end{array}$ & & 31.5 & $\begin{array}{l}\text { Late } \\
\text { Miocene }\end{array}$ \\
\hline
\end{tabular}

\section{Unit I}

Unit I consists of nannofossil ooze and marl of Quaternary age. It is divided into two subunits on the basis of slight differences in composition and physical properties.

\section{Subunit Ia}

Subunit Ia comprises mottled, greenish-gray nannofossil marl which is very soft and was moderately to strongly deformed during coring. X-ray diffraction indicates the presence of some high magnesium calcite, as well as serpentine and chlorite, in the sediments. Interbedded with the marls are two layers of pebble conglomerates, one 2.65 meters thick and the other 13 $\mathrm{cm}$ thick. This sediment consists of rounded clasts of marl and marlstone from a few millimeters up to $8 \mathrm{~cm}$ in diameter. Various colors and consistencies of marls and marlstones are present, from dark, firm clasts to soft, pinkish-gray ones. These reside in a pinkish-gray marl matrix, and in most parts of the conglomerate the clasts are tightly packed. Nannofossils examined in several of these clasts belong to somewhat different assemblages, but all are of the same zonal age. We interpret these as sedimentary slump conglomerates, probably formed by downslope slumping of Quaternary pelagic marls and marlstones.

Olive-gray to black sapropelic marls in layers 2 to $19 \mathrm{~cm}$ thick also occur interbedded with the nannofossil marls. These vary from slightly to intensely burrowed; Chondrites being the dominant form.

\section{Subunit Ib}

Subunit $\mathrm{lb}$ consists of nannofossil marl and ooze, which is generally greenish-gray, olive-gray, or bluishgray. Consistency varies from firm near the top to soft, and intensely deformed by coring, lower in the unit.
Most of the sediment shows faint and subtle color mottling, suggestive of slight to moderate burrowing, but distinct burrows become visible only in the sapropelic units as described below.

Compositionally, the marls and oozes have $40 \%$ to $50 \%$ clay minerals, and $30 \%$ to $50 \%$ nannofossils. In contrast to Unit Ia, the calcite in these sediments is largely low magnesium calcite and serpentine and chlorite are less abundant; unspecified carbonate, including small dolomite rhombs, is $5 \%$ to $10 \%$; fine quartz and foraminiferal tests are $5 \%$ or less. Measured carbonate contents range from $54 \%$ to $62 \%$. Pyrite, in some cases as small pyritized burrows, is usually present in trace amounts, and rare volcanic glass fragments are present in some, but not all, samples examined.

Several layers of sapropelic marl occur interbedded with the marls and oozes. They are olive-gray to black, slightly to moderately burrowed layers 4 to $13 \mathrm{~cm}$ thick, but mostly in the range 6 to $8 \mathrm{~cm}$. Significant sapropelic intervals occur in Sections 1 and 2, Core 1, and in Section 3, Core 3 of Hole 378. They consist of $25 \%$ to $40 \%$ fine-grained organic matter, $15 \%$ to $50 \%$ nannofossils, $0 \%$ to $30 \%$ clay minerals, rare to $5 \%$ forams and quartz, and an estimated $10 \%$ to $20 \%$ carbonate. Some of the layers have sharp basal contacts, but have a transitional upper zone at their tops; in some cases this zone is a gradation between sapropel and marl, in others it consists of thinly interlayered marl and sapropelic marl layers. Typically this upper zone is riddled with small Chondrite burrows.

Volcanic ash occurred only in the core catcher of Core 4, Hole 378; only a small amount was present, and the thickness of the layer could not be determined. Unit I represents Quaternary hemipelagic deposition with periodic episodes of bottom stagnation. We were surprised at the very small amount of volcanic ash present. 


\section{Unit II}

Unit II is firm and coherent, gray, nannofossil marlstone of late Pliocene age. The degree of drilling disturbance varies from slight to moderate. Interlayered dark sapropelic marlstones are common and prominent. The unit is moderately to intensely burrowed throughout; Planolites and Chondrites are common, and minor Zoophycos is also present. Color varies from light bluish-gray to grayish-olive to greenish-gray to pale green; greenish-blues are somewhat more prominent toward the base of the unit.

Compositionally these marlstones are very similar to the sediments of Unit I, except for somewhat lower amounts of clay minerals $(30 \%-40 \%)$ and higher amounts of unspecified carbonate (10\%-20\%). The latter may reflect the onset of diagenetic carbonate cementation. The third major component is nannofossils (30\%-50\%). Also present are rare to trace amounts of quartz and pyrite. In Cores 7 and 8, Hole 378, the marlstones contain scattered siliceous microfossils (diatoms, Radiolaria, sponge spicules) with, in a few cases, up to $20 \%$ diatom frustules. A coarse fraction from Section 2, Core 8 contained abundant clear volcanic glass. Measurements of total carbonate content give a range of $43 \%$ to $65 \%$, with an average of about $52 \%$.

Numerous thin $(2-6 \mathrm{~cm})$ sapropel and sapropelic layers occur throughout the unit. Most contain 30\% to $50 \%$ nannofossil material. Especially prominent dark layers occur in Sections 1 and 2 of Core 8. These have $20 \%$ to $40 \%$ diatoms, plus smaller amounts of sponge spicules, Radiolaria, and silicoflagellates. The sapropel in the upper part of Section 2, Core 8 is $43 \mathrm{~cm}$ thick, of which $28 \mathrm{~cm}$ is finely laminated sparsely burrowed, diatomaceous sediment; this sediment also contains unusual, small elliptical-shaped pockets of tephra, which are either burrow fillings (from an unknown source) or redeposited pieces of volcanic sediment.

As in Unit I, some of the Unit II sapropelic layers show a distinctive sequence of sedimentary structures. This begins with a very sharp basal contact against the underlying marlstones. The upper contact, in contrast, is gradational from dark to increasingly lighter gray colors so that the sapropelic unit gradually changes into normal marlstone. In addition, this upper transitional zone is usually moderately to intensely burrowed, whereas the basal part of the thicker sapropelic layers may be fine-grained turbidites, with sharp (erosional) lower bedding planes (for further discussion see Kidd et al., this volume).

The depositional settings of Units I and II appear to have been similar, except that at times siliceous components became a significant portion of Unit II sediments. Additionally, burrowing apparently affected Unit II sediments to a much greater degree. The main differences, however, seem to have been those imposed by diagenesis, which included compaction and possibly some cementation to produce coherent marlstones.

\section{Unit III}

Unit III comprises early Pliocene, drab gray nannofossil marlstones, like Unit II only harder, with very abundant organic-rich sapropelic marl interlayers, and with more numerous and varied burrows. In addition to Chondrites and Planolites, Unit III marlstones contain Teichichnus and prominent Zoophycos. The color range is the same as in Unit II.

Compositionally, marlstones in Unit III are also much like those in Unit II; the major difference is more abundant serpentine in Unit III (3\% to $5 \%$ as compared with $1 \%$ in Unit II), which suggests detrital input was more significant in this unit. Three components dominate: clay minerals $(30 \%-40 \%)$, nannofossils $(30 \%-50 \%)$, and unspecified carbonate $(5 \%-30 \%$, most in the range of $10 \%-20 \%$ ). Total carbonate measurements of three samples had a range of $50 \%$ to $57 \%$.

The sapropelic intervals vary from 1 to $15 \mathrm{~cm}$ thick and some consist of finely interlayered dark sapropelic marlstone and light colored marlstone. Although more numerous than in either Units I or II, these sapropelic layers seem less organic rich judging by their generally lighter colors. Also, the sapropelic layers in Unit III (especially in Core 11) contain fairly abundant benthic foraminifers. These observations suggest that Unit III sapropelic layers represent deposition on a sea floor where sufficient oxygen existed to support a rather diverse benthic community. X-ray diffraction and smearslide observations indicate minor amounts of finegrained gypsum in some of the sapropelic intervals (e.g., Samples 11-1, $149 \mathrm{~cm}$ and 11-2, $2 \mathrm{~cm}$ ).

\section{Unit IV}

Unit IV comprises very coarsely crystalline, yellowish to olive-gray selenitic gypsum, apparently as a thick unit or as several separate, thick layers between subbottom depths 302 and 331 meters. Individual elongated gypsum crystals are of the "swallowtail" type and are up to $8 \mathrm{~cm}$ long. Very commonly the elongation of these coarse crystals is perpendicular or nearly so to bedding, and they appear to have grown upward in rosette-like clusters. Considerable void space exists between some of these clusters, giving the rock a vuggy appearance. There seems to be no sediment either between or within the crystals, although some of them have a somewhat occluded appearance as if they contained many, very small inclusions. In any event, there are no clearly discerible relic outlines of laminae or bedding within these crystals to show that they replaced a host sediment. In thin sections, some of the selenite crystals contain fecal pellets, probably produced by brine shrimps.

At the top of Core 4 in Hole 378A, there is a drilling contact which artificially emplaces gray marlstone and sapropel of Pliocene age (MPl-2) on top of coarse gypsum of Miocene age. The core catcher of Core 11, Hole 378, contained two pieces of limestone, which are surmised to occur stratigraphically above the gypsum but below the Pliocene nannofossil marlstone. This limestone is a rather porous breccia consisting of subangular to subrounded, pebble-size clasts of micritic limestone cemented in a micritic to microspar matrix. The matrix contains irregular vugs up to $1 \mathrm{~cm}$ long. Some of the vugs are lined with anhedral, clear carbonate crystals. The micritic limestone clasts appear 
largely recrystallized, although a few seem to have poorly preserved pellets and one clast contains what might be algal structures. According to B. C. Schreiber, who examined thin sections of this material, the rock closely resembles weakly cemented carbonate intraclasts, which occur beneath Messinian evaporites on Sicily. There she interprets the carbonate alteration as the product of subaerial exposure (Schreiber, personal communication, 1975).

In Hole 378, Cores 7 and 9 had no recovery, apparently because the bit had been damaged and could not cut core. Core 8 recovered only a few crystals of selenitic gypsum plus Pliocene nannofossil ooze, both of these are undoubtedly contaminants. The drilling bit, when finally retrieved, was coated with fine-grained gypsum and soft gray mud.

\section{GEOCHEMICAL MEASUREMENTS}

The geochemical data from both sites, which are separated by a distance of only 10-12 meters, are combined.

\section{Interstitial Water}

Shipboard geochemical data on interstitial waters are plotted in Figures 5 and 6 and represented in full in Table 4 . The salinity (Figure 5) remains nearly constant except for a slight increase in the sample taken just above the evaporite. The calcium concentration (Figure 6) is also nearly constant except for the significant increase to $40+\mathrm{mM} / 1$ just above the evaporite. The alkalinity (Figure 5) shows a parallel trend, with a corresponding decrease where the calcium-concentration increases. The magnesium concentration remains nearly constant at a value slightly below that of normal seawater. The chlorinity is constant down to the sample laying directly above the evaporite.
The data suggest that the selenitic gypsum is a diffusion barrier, effectively preventing ionic migration from brines which may be present at depth. The high salinity of the interstitial water in sediments immediately above the gypsum is related to its chemical equilibrium with gypsum, resulting in a $\mathrm{CaSO}_{4}$-saturated and slightly more saline brine.

\section{Carbonate Content}

The mean carbonate content (see plot with hole summary) of the sediments of Plio-Quaternary age is between $40 \%$ and $50 \%$. Only Core 1 of Hole 378A shows a lower mean, with values ranging between $8 \%$ and $46 \%$, due to a higher input of terrigenous and volcanic material. The main source of the $\mathrm{CaCO}_{3}$ is nannofossil material.

\section{Total Carbon}

Shipboard measurements of the carbon content of two samples of sediment from "dark layers" at Site 378 gave the following results:

\begin{tabular}{lcc} 
Sample & $3-3,118-119 \mathrm{~cm}$ & $8-2,45-46 \mathrm{~cm}$ \\
\hline Weight \% & & \\
Total Carbon & $10.6-11.1$ & 9.5 \\
Organic Carbon & $6.2-6.5$ & $5.4-5.6$ \\
$\mathrm{CaCO}_{3}$ & 37.5 & 32.5
\end{tabular}

The high organic carbon content confirmed the suggestion that both layers are sapropels.

\section{PHYSICAL PROPERTIES}

\section{Sonic Velocity}

Compressional velocities in the nannofossil oozes and marlstones above the evaporite layer at 303 meters subbottom are unusually low ( 1.5 to $1.7 \mathrm{~km} / \mathrm{sec}$ ) at this site and show almost no tendency to increase with

TABLE 4

Summary of Shipboard Geochemical Measurements, Site 378

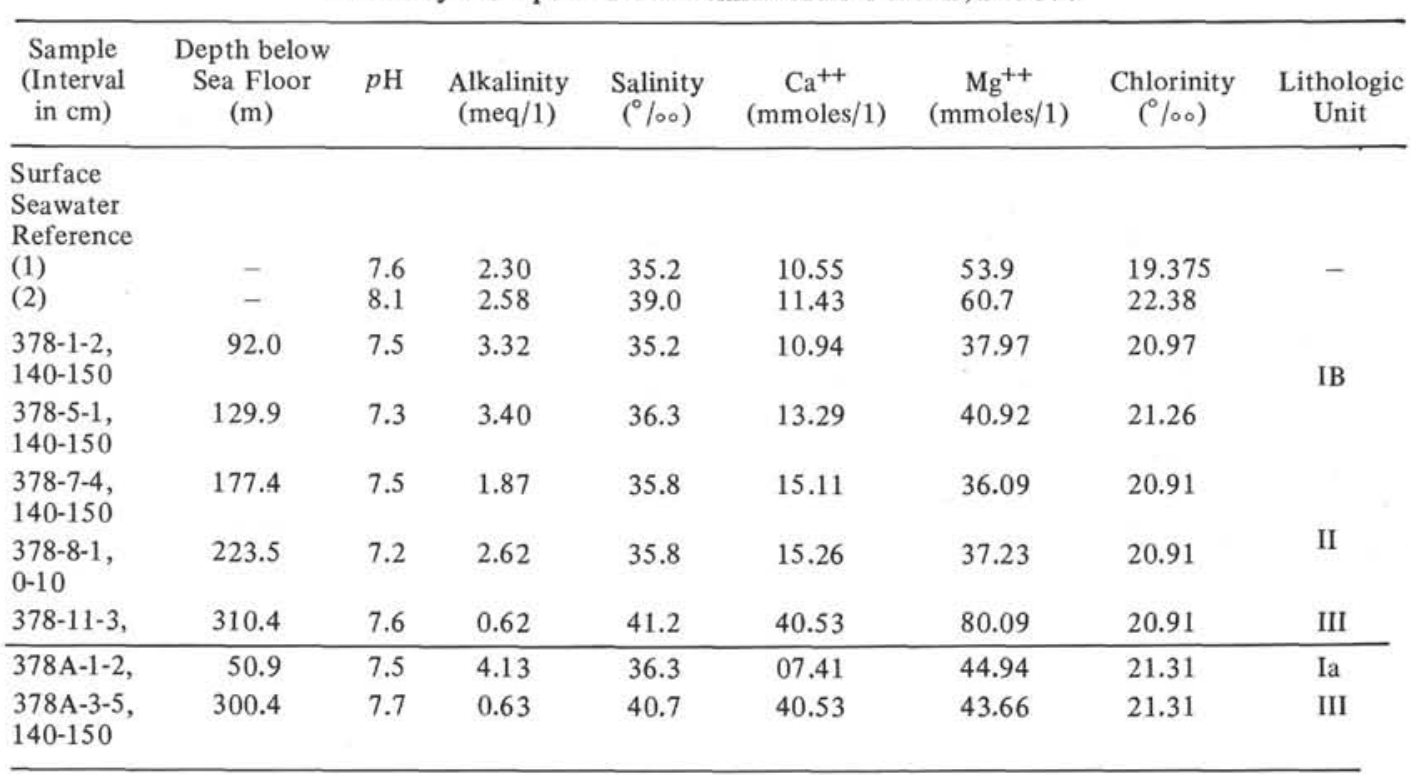



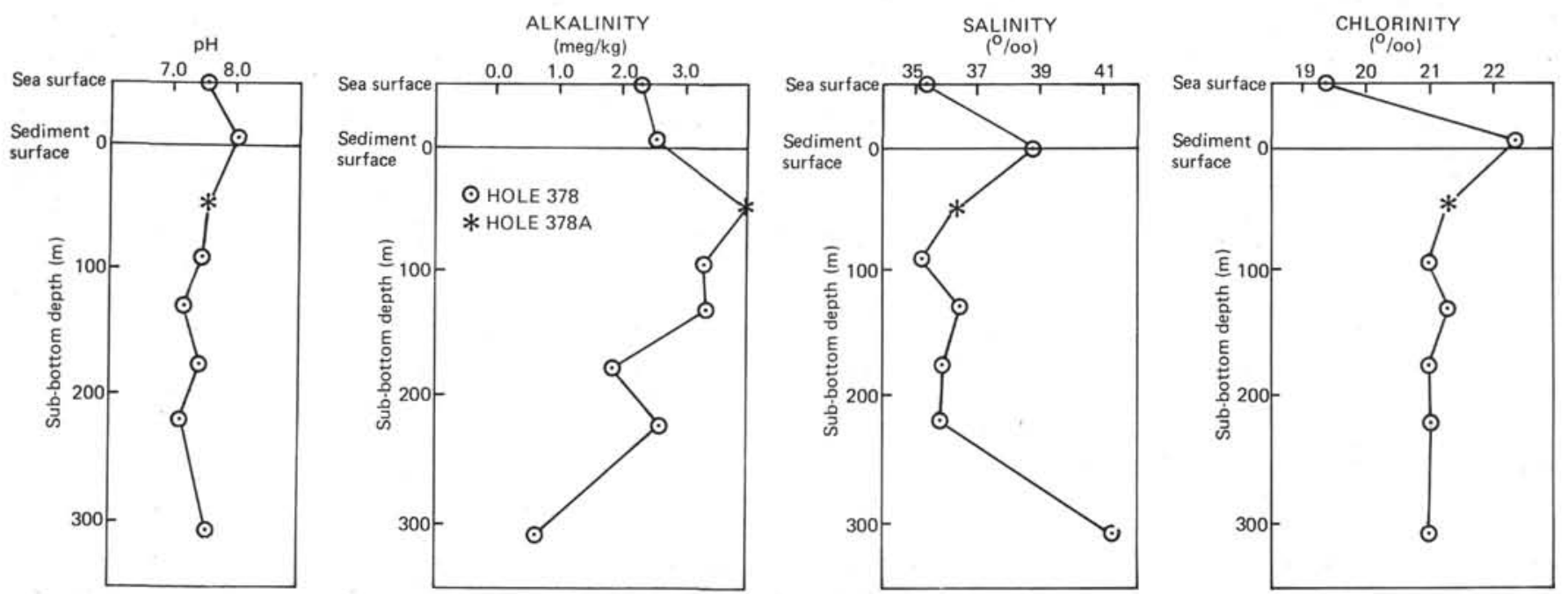

Figure 5. Geochemical measurements at Site 378: $\mathrm{pH}$, alkalinity, salinity, and chlorinity.

depth between 50 and 300 meters subbottom (Figure 7 and Table 1 of Appendix VI). Much higher velocities were measured through chunks of coarsely crystalline, selenitic gypsum recovered below 303 meters (Table 2 of Appendix VI). It is interesting that velocities measured in the horizontal direction are systematically lower by an average of $22 \%$, than the vertical velocities. Both the very large difference between the horizontal and vertical velocities, and the fact that the vertical velocity is lower than the horizontal velocity, are unique to this site. This is probably explained by the observation that the chunks consisted of aggregates of elongate gypsum crystals up to $8 \mathrm{~cm}$ in length and oriented vertically. The velocity of sound is higher parallel to the long axis of the gypsum crystals than perpendicular to it, and there is better mechanical contact parallel to the axis. These are two possible factors in causing the observed anisotropy.

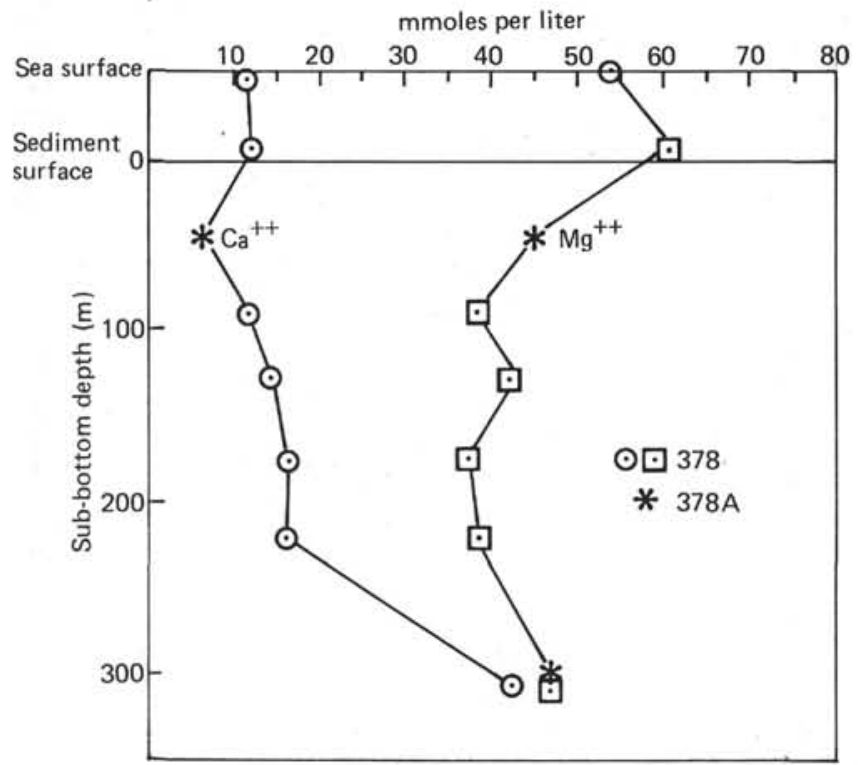

Figure 6. Geochemical measurements at Site $378 \mathrm{Ca}^{++}$ and $\mathrm{Mg}^{++}$.

\section{Bulk Wet Density, Porosity, and Water Content}

The values of wet bulk density listed in Table 3 of Appendix VI and plotted versus depth in Figure 8 are the maximum density values recorded in a $15-\mathrm{cm}$ interval of the core section as the section moved slowly through the gamma ray apparatus. These data, along

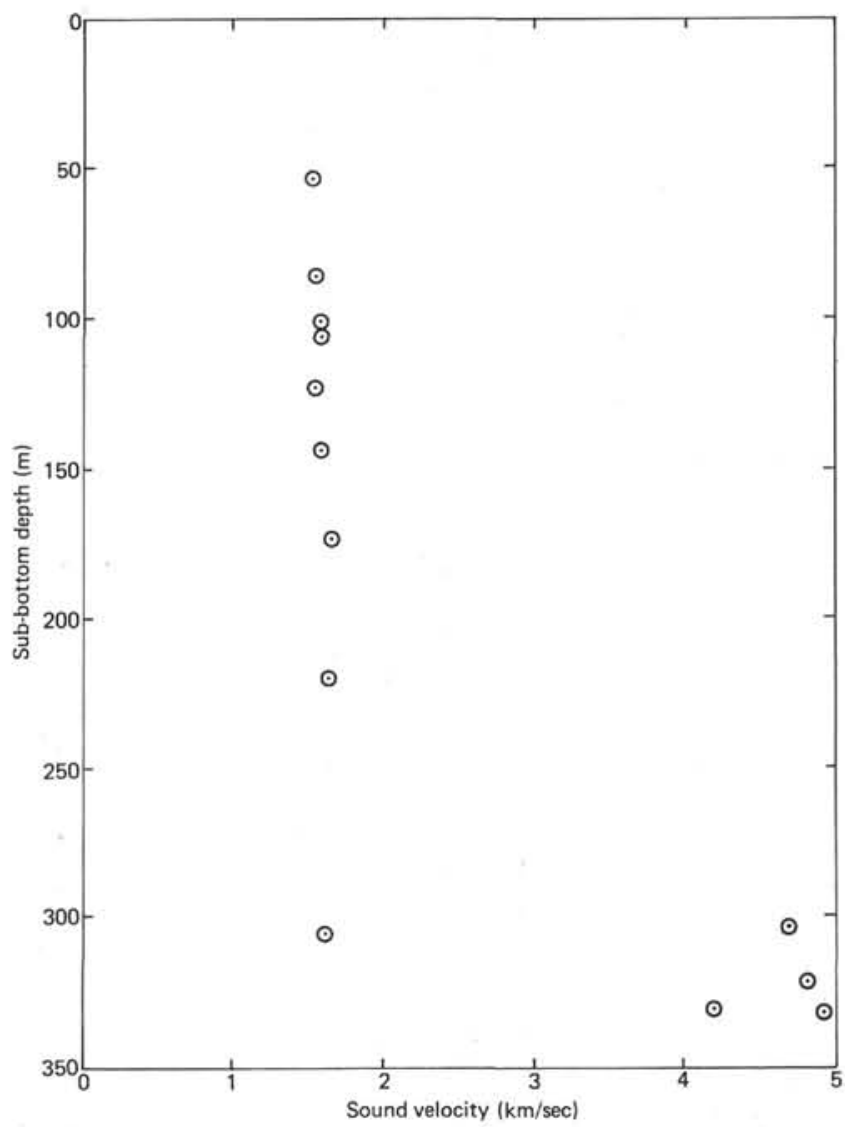

Figure 7. Sound velocity measured in the horizontal direction through sediments recovered at Site 378, plotted versus subbottom depth. 


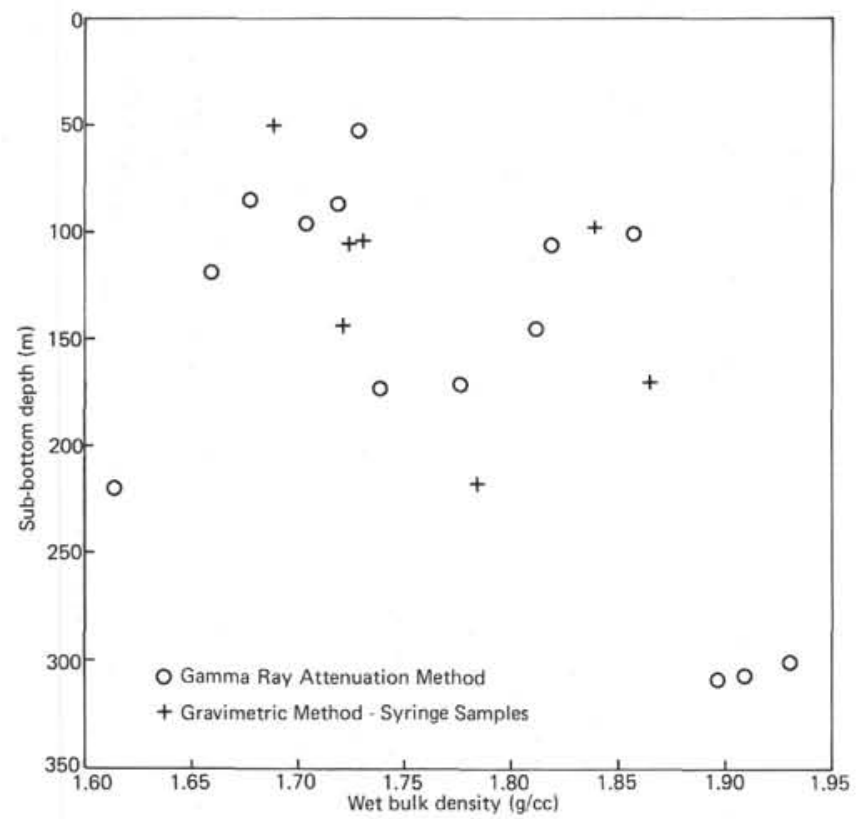

Figure 8. Wet-bulk density determined on sediments recovered from Site 378, plotted versus subbottom depth.

with the other gravimetric data are listed in Tables 4 and 5 of Appendix VI.

In sharp contrast to the very low variability of the sound velocity data measured between 50 and 300 meters subbottom, the bulk wet density data have such large variability that it is only with difficulty that a weak general increase in density with depth can be discerned. As usual, the syringe data have much higher variability than the gamma ray attenuation data. Both types of data suggest a poorly defined increase in density with depth from below 50 meters subbottom to just above the top of the evaporite layer.

\section{Thermal Conductivity Data}

Values range from $2.34 \mathrm{mcal} / \mathrm{cm} \mathrm{sec} / \mathrm{C}$ at 53 meters subbottom up to $3.21 \mathrm{mcal} / \mathrm{cm} \mathrm{sec}{ }^{\circ} \mathrm{C}$ at 306 meters (Table 7 of Appendix VI). An even higher value of $3.52 \mathrm{mcal} / \mathrm{cm} \mathrm{sec}{ }^{\circ} \mathrm{C}$ was determined at 300 meters subbottom, however the measurement was either in or very near to a sapropel layer and thus may not be representative of the dominant lithology (nannofossil marl and marlstone). The mean conductivity at Site 378 (combining data from Holes 378 and $378 \mathrm{~A}$ ) is $2.88 \pm 0.37 \mathrm{mcal} / \mathrm{cm} \mathrm{sec}^{\circ} \mathrm{C}$.

Despite the absence of data in the interval between 175 and 300 meters, a clearcut increase in thermal conductivity with depth is apparent in Figure 9. On the basis of the nearly homogeneous lithology, it is probable that the downward thermal conductivity data increase is due to compaction.

\section{BIOSTRATIGRAPHY}

\section{Summary}

At Hole 378, coring was continuous in the Quaternary sequence from Core 1 to Core 5 , discontinuous from Core 6 to Core 8 , and continuous again from

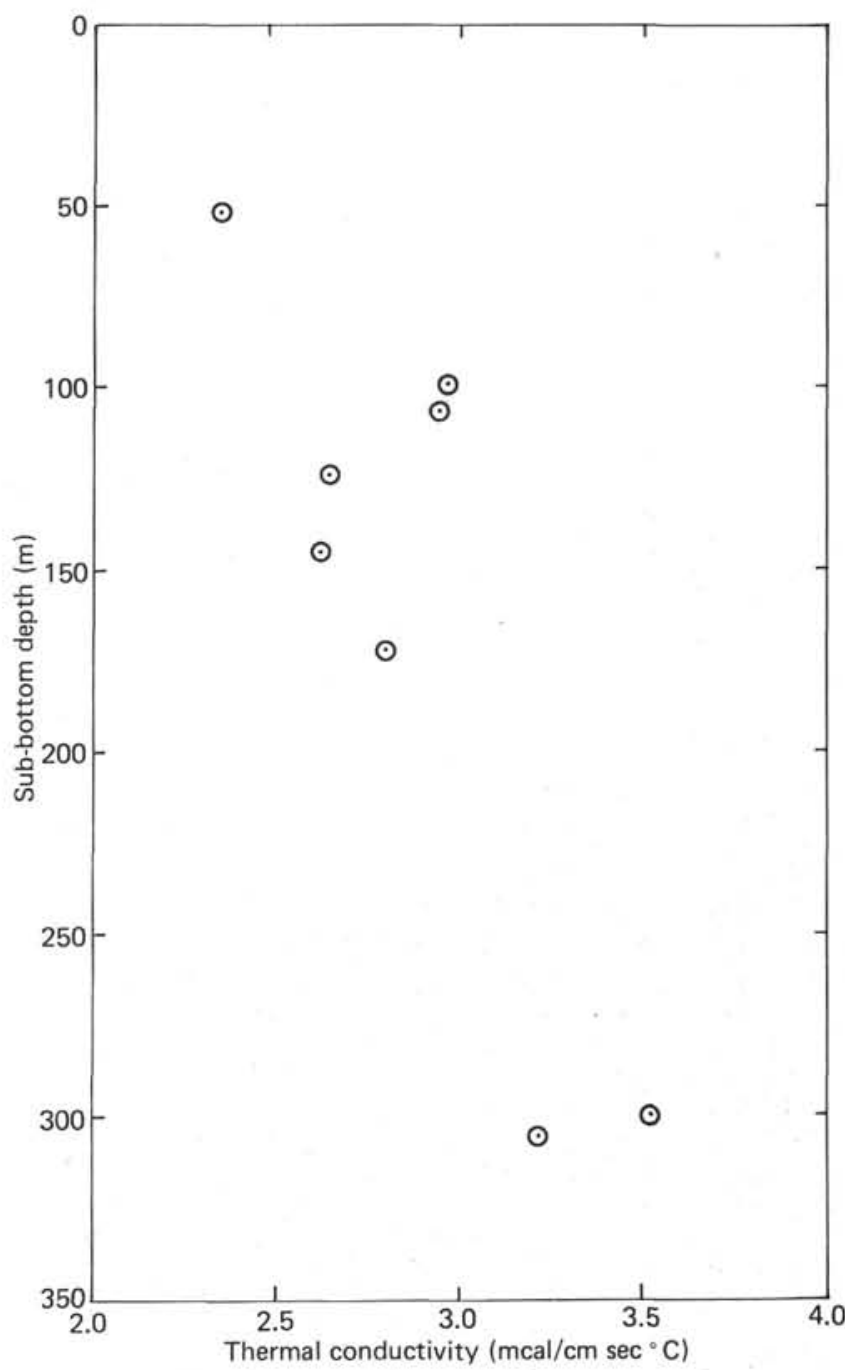

Figure 9. Thermal conductivity determined aboard ship on sediments recovered from Site 378, plotted versus subbottom depth.

Core 9 to Core 11 in the lower Pliocene. Cores 9 and 10 had very poor recovery. Hole $378 \mathrm{~A}$ was continuously cored from lower Pliocene Core $2(280.5 \mathrm{~m}$ subbottom) to the evaporite rocks recovered in Cores 4 to 9 (down to $343.5 \mathrm{~m}$ subbottom).

Quaternary sediments were recovered in Cores 1 to 4 (84.0 to $122.0 \mathrm{~m}$ subbottom) in Hole 378 and in Core 1 ( 48 to $55.0 \mathrm{~m}$ subbottom) in Hole $378 \mathrm{~A}$ (Figure 10.) The well-preserved foraminiferal and nannofossil assemblages are diversified. The presence of tunicate spicules, shell fragments, and reworked species indicates some displacement of shelf materials.

The Pleistocene-Pliocene boundary is variously placed at Sample 378-4, CC, (Müller) on nannofossil evidence, or Sample 378-5-1, $124 \mathrm{~cm}$ (Bizon), or between Cores 5 and 6 of Hole 378 (Cita), both on planktonic foraminiferal evidence.

An apparently complete sequence of the upper Pliocene was encountered below Core 5 to Sample 9, CC (122.0 m to $283.5 \mathrm{~m}$ subbottom) in Hole 378. The sediments are rich in planktonic and benthic foraminifers. The nannofossils here are well preserved to 


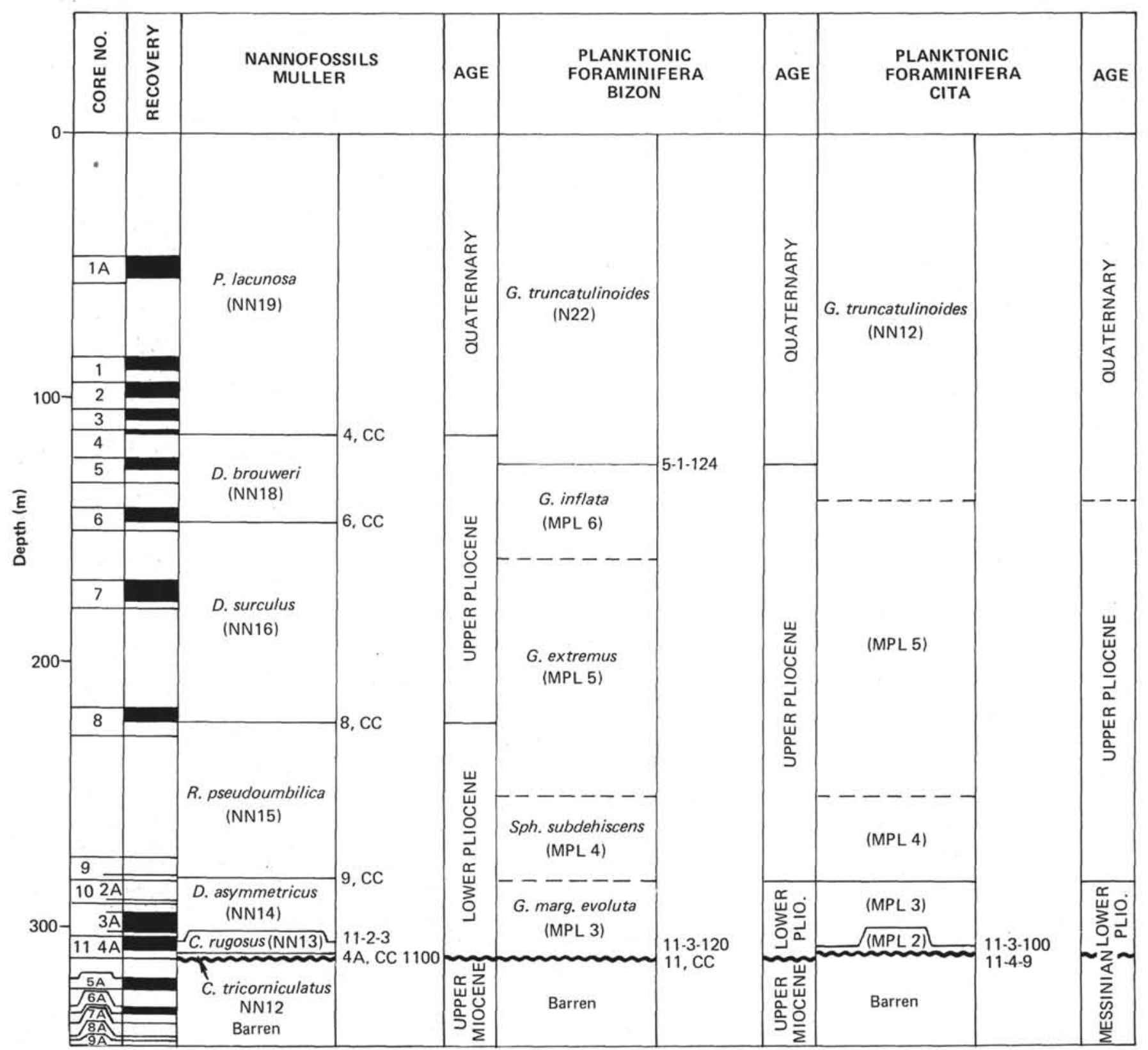

T. D. $=343.5$ meters

Figure 10. Relative planktonic microfossil determinations: Holes 378 and $378 \mathrm{~A}$.

slightly overgrown. Diatoms, silicoflagellates, Radiolaria and sponge spicules are abundant in Core 5, Sections 1 and 2 and in Cores 7 and 8, but are mainly restricted to the sapropels and sapropelic layers of this upper Pliocene sequence.

A lower Pliocene age was determined for Samples $10, \mathrm{CC}$ to $11, \mathrm{CC}$ in Hole $378(283.5$ to $312 \mathrm{~m}$ subbottom) and for Samples 2, CC to 4-1, CC (280.5 to $302.5 \mathrm{~m}$ subbottom) in Hole $378 \mathrm{~A}$. The sediments in general are rich in well-preserved and diversified foraminiferal and nannoplankton assemblages. The lower Pliocene in Hole 378 A is underlain by evaporites in Cores 4 to 8 ( 302.5 to $342.5 \mathrm{~m}$ subbottom).
Nannofossils

\section{Quaternary (Hole 378)}

Pleistocene ages (Pseudoemiliania lacunosa Zone, NN 19) were recorded for Core 1 to Sample 4, CC (84.0-122.0 m subbottom). Nannofossil assemblages show high species diversity and preservation is good. The presence of more or less detrital material, reworked species, and tunicate spicules indicate an input of material which was originally deposited in shallow water. Common species are: Pseudoemiliania lacunosa, Syracosphaera pulchra, Rhabdosphaera clavigera, Gephyrocapsa oceanica and Discolithina japonica. Nanno- 
fossils in the sapropels and sapropelic layers are slightly etched. In Sample 3-3, 110-111 cm, a large variety of Braarudosphaera bigelowi is common. This horizon is probably comparable with the Braarudosphaera bigelowi horizon of the lowermost part of the Pseudoemiliania lacunosa Zone in the Tyrrhenian Sea (Site 132, Leg 13) and in South Balearic Basin (Site 371).

\section{Quaternary (Hole 378A)}

A Pleistocene diversified nannoplankton assemblage of the Pseudoemiliania lacunosa Zone (NN 19) is present in Core 1 (46.0-55.5 m subbottom). The sediments here are abundant in well-preserved nannofossils. Mud pebbles, of differing colors, present in Core 1, Section 2 and the upper part of Section 3, contain the same assemblages only with slight differences in abundance of species. Rhabdosphaera stylifer, Umbilicosphaera mirabilis, Syracosphaera pulchra, Discolithina sp. Gephyrocapsa oceanica, Helicosphaera carteri, and Pseudoemiliania lacunosa are the most important species of this sequence. In some samples a few reworked Pliocene species were observed.

\section{Pliocene (Hole 378)}

The Discoaster brouweri Zone (NN18) was determined from Samples 5-1, $81-82 \mathrm{~cm}$ to $6, \mathrm{CC}$. The PlioPleistocene boundary is placed in Sample 4, CC, using the extinction of Cyclococcolithus macintyrei because discoasters are rare in this sequence. Discoaster brouweri is missing in Sections 1 and 2 of Core 5, a few specimens were found in Sample 5, CC. This species is common only in Samples 6-3, 20-21 cm and 6-3, 80-81 $\mathrm{cm}$. Nannofossils of the dark (sapropel) layers (6-1, $145-146 \mathrm{~cm}, 6-2,17-18 \mathrm{~cm}$, and 6-3, 100-111 cm) are slightly etched and discoasters are broken. Diatoms, silicoflagellates, and sponge spicules are present in Sample 5-1, 81-82 $\mathrm{cm}$ and sponge spicules only in Sample 5-2, 111-112 cm. Sample 5, CC is rich in volcanic ash, while nannofossils are rare due to dilution.

The Discoaster surculus Zone (NN 16) was determined from Samples 7-1, 60-61 cm to 8, CC (169.5$226.5 \mathrm{~m}$ subbottom). The nannofossils are well preserved to slightly overgrown. Discoasters are rare or are missing in Sections 1 and 2 of Core 7; Discoaster brouweri and Discoaster pentaradiatus are common from Sample 7-3, 40-41 cm, while Discoaster surculus was found only sporadically. This later species becomes frequent from Section 5 of Core 7. The sapropel layer at 7-4, $81-82 \mathrm{~cm}$ and the sediments of Core 8 are rich in diatoms, silicoflagellates, and sponge spicules.

The upper Pliocene zones are relatively thick, whereas those of the lower Pliocene are much reduced in thickness. This suggests that a change in conditions of sedimentation occurred in the Pliocene.

Sample 9, CC $(283.5 \mathrm{~m})$ belongs to the Reticulofenestra pseudoumbilica Zone (NN 15). This sample is abundant in well-preserved coccoliths, while its discoasters are slightly overgrown. Discoaster tamalis and Discoaster asymmetricus are common. The
Discoaster asymmetricus Zone (NN 14) is present in Sample 10, CC to Section 11-2, top (292.0-304.0 m subbottom); Ceratolithus tricorniculatus is only rare, while Scyphosphaera globulata becomes frequent, as is typical for this zone.

The interval between Samples 11-2, 3-4 cm and 11$4,38-39 \mathrm{~cm}(304.0-307.0 \mathrm{~m}$ subbottom) belongs to the Ceratolithus rugosus Zone (NN 13). The sediments of this zone are abundant in well-preserved to slightly overgrown nannofossils. The assemblages display high diversity. Reworked species are absent. Coccoliths in the sapropel layers are slightly etched whereas discoasters are often broken. Discoasters are common in this sequence while ceratoliths are frequent only in the lower part.

The Ceratolithus tricorniculatus Zone (NN 12) was determined from Samples 11-4, 48-49 $\mathrm{cm}$ to 11, CC $(307.0-312.0 \mathrm{~m})$. Its sediments are rich in well-preserved nannoplankton. Coccoliths are etched and partially diminished by dissolution in the sapropel layers, while discoasters are relatively enriched but broken.

\section{Pliocene (Hole 378A)}

That part of the hole from Samples 2, CC to 3-1, $140-141 \mathrm{~cm}(280.5-294.5 \mathrm{~m})$ belongs to the Discoaster asymmetricus Zone (NN 14) of the lower Pliocene. Its coccoliths are slightly etched, while its discoasters are overgrown. Discoaster brouweri, Discoaster pentaradiatus and Discoaster surculus are abundant. Only a few specimens of Ceratolithus rugosus and Ceratolithus triborniculatus were found. The nannoplankton assemblage of this zone displays high species diversity.

The Ceratolithus rugosus Zone (NN 13) was determined from Samples 3-2, 10-11 cm to 4, CC (294.5$312.0 \mathrm{~m}$ ). The assemblages of this part of the profile are diversified. Preservation is excellent in the sapropelic interlayers of Core 3 , while discoasters are slightly overgrown in some samples of the marls. Scyphospheres (mainly Scyphosphaera conica) and discoasters become abundant in some samples of this sequence. Other species recorded are Ceratolithus tricorniculatus, Ceratolithus rugosus (in general, rare), Reticulofenestra peudoumbilica, Helicosphaera carteri, Cyclococcolithus macintyrei, Sphenolithus abies, and Rhabdosphaera stylifer.

The Ceratolithus rugosus Zone is underlain by gypsum. The lowermost Pliocene (Ceratolithus tricorniculatus Zone, NN 12) was not determined in this hole.

\section{Planktonic Foraminifers (Cita)}

Fifty-three sediment samples taken onboard ship were investigated from Hole 378 and 17 from Hole $378 \mathrm{~A}$ in Cretan Basin through a 310 -meter-thick PlioPleistocene succession overlying the Mediterranean evaporite. An additional four samples from each hole were examined after sampling at the shore repository. Eighteen of the samples from Hole 378 and 1 of those from Hole 378A were from sapropels or sapropelic layers. 
Reference should be made to Bizon et al. (this volume) where detailed range charts show the distribution of 44 species and/or subspecies of planktonic foraminifers, together with other fossils recorded and several characteristic inorganic components found in the sand-size fraction. Kidd et al. (this volume) describe in detail the sapropels and sapropelic layers and discuss their origin.

\section{Pleistocene}

Hemipelagic sediments of Pleistocene age with numerous sapropelic interbeds occur in Cores 1-5, Hole 378 (84-131 m subbottom) and in Core 1, Hole 378A (46-55 m subbottom). They are referred to the Globorotalia truncatulinoides total range zone, although the zonal marker is only occasionally recorded in Cores $378-1$ and 378A-1. The foraminiferal faunas are rich and diversified. They clearly show the interaction of sedimentary processes, volcanic activity, climatic fluctuations, and stagnant cycles through the Quaternary record of the Cretan Basin.

\section{Pliocene-Pleistocene Boundary}

Because of the drilling schedule adopted at Site 378 (spot coring and an open core barrel when washing down), it is difficult to pinpoint the Pliocene/Pleistocene boundary. The foraminiferal assemblages yielded by Core 5 , Hole 378 , are clearly referable to the Pleistocene. Sediments from the topmost part of Core 378-6 are also possibly Quaternary in age, but they may be downhole contaminants. Consequently, it is suggested by this author that sedimentation rates should be calculated assuming a Pliocene/Pleistocene boundary located arbitrarily halfway between Cores 5 and 6 .

\section{Late Pliocene}

Sediments of late Pliocene age were recovered from Cores 6 to 8, Hole 378, and from Core 2, Hole 378A. The zonal subdivision is as follows.

\section{MPl-6}

The occurrence of this biozone in Hole 378 is doubtful. In the 10 samples examined from this hole, Globigerinoides obliquus extremus is recorded in most samples, while primitive forms of Globorotalia inflata are recorded in Sample 378-6-3, 140-142 cm.

\section{MPl-5}

This biozone was determined with typical assemblages in Cores 6, 7, and 8 at Site 378. It is characterized by several stagnant cycles, as at the other eastern Mediterranean drill sites $(374,376)$. The two sapropel layers recorded in Core 8 (both greenish in color, and with a "tea-leaf" appearance, (see Kidd et al., 1977) are rich in siliceous microfossils; essentially sponge spicules and Radiolaria in Sample 8-1, $124 \mathrm{~cm}$ and the same, plus extremely abundant diatoms, in Sample 8-2, $45 \mathrm{~cm}$.

\section{MPl-4}

The Sphaeroidinellopsis subdehiscens interval zone has been identified at both holes (378-9 and 378A-2) at approximately 280 meters subbottom. In both cases only the core catcher was recovered with traces of a very sticky lithology. The sand-size fraction of the sediment consists entirely of foraminiferal tests which are mostly planktonic.

\section{Early Pliocene}

\section{MPl-3}

This biozone has been identified in Cores 10 and 11 (down to Section 3,100 cm) at Site 378 and in Core 3 (down to Section $6,7 \mathrm{~cm}$ ) in Hole 378A. A drastic change in sedimentation rate is recorded in the early Pliocene at this site corresponding to the MPl-3 biozone. This suggests that a significant change occurred in sediment dispersal at this time. Several dark layers are present in the MPl-3 zone. Unlike most sapropels, they are intensely burrowed and moreover yield benthic foraminifers and other bottom-living organisms as readily as in the "normal" background sediment in which the layers are set. In these black layers, planktonic foraminifers are rare to abundant, and in most cases are poorly preserved. Gypsum and dolomite crystals were recorded in the samples taken from the dark layers at $149 \mathrm{~cm}$ in Section 1 and at 2 $\mathrm{cm}$ in Section 2 of Core 11, Hole 378.

\section{MPl-2}

This biozone has been identified at both holes in the lowermost part of the hemipelagic sequence and unconformably overlies the sediments of the Mediterranean evaporite formation. It spans Core 378-11, down core from Sample 11-4, $9 \mathrm{~cm}$ and Core 378A-3, down core from Sample 3-6, $99 \mathrm{~cm}$. Faunal assemblages are rich and diversified, yielding up to 16 discrete taxa (see Bizon et al., Chapter 49, this volume) and including the zonal marker Globorotalia margaritae margaritae.

\section{Miocene/Pliocene Boundary}

The abrupt contact observed at the top of Section 1, Core 4, Hole 378A, is considered a drilling artifact (see Operations Report). The olive-gray marls, with a dark layer at the top, yielded rich foraminifer assemblages of MPl-2 age. They are in contact with selenitic gypsum. Marls of MPl-2 age are recorded in the lowermost part of Section 378-11-6, as well as in its core catcher where they are associated with a dolomitic limestone breccia which probably lies stratigraphically above the selenitic gypsum.

The earliest Pliocene MPl-1 zone is missing.

No fossiliferous sediments of pre-Pliocene age were recovered in Hole 378. The lithology of Unit 4 clearly suggests an abiotic environment. A sample processed from the gypsum lodged in the drill bit yielded three individual foraminiferal tests, Globigerinoides trilobus, G. obliguus extremus and Bulimina sp., plus one fragment of echinoid spine. 


\section{Comments on the Paleoclimate of the Cretan Basin}

Although coring was quite discontinuous in the Cretan Basin, a few remarks may be added concerning some paleoclimatic aspects of the faunal assemblages investigated. Generally speaking, the foraminiferal faunas of Pleistocene age recovered from the Cretan Basin indicate cooler conditions than those recorded at DSDP Sites 125 and 132 (see Ryan, Hsü, et al., 1973). Warm water indicators are poorly represented. In particular Globigerinoides sacculifer is seldom recorded, while neither Hastigerina pelagica nor Globigerina digitata were noticed in any of the 24 samples investigated. As far as Site 125 is concerned, the "cooler" conditions might be ascribed to its more northerly location. However this same effect is not applicable to the Tyrrhenian drill site (Site 132). Local continental conditions and/or the influence of cold currents may be a more plausible cause.

The "brown" cool climatic episode characteristic of Zone MPI-4 and the "red" warm climatic episode of the later part of MPl-3 could be recognized in the Cretan Basin on the basis of the same observational data originally used (see Ciaranfi and Cita, 1973) to identify these Pliocene climatic fluctuations.

\section{Planktonic Foraminifers (Bizon)}

\section{Quaternary (Hole 378)}

Cores 1 to 3 are Quaternary in age. Globorotalia truncatulinoides was not found in the sediments at this site. Globorotalia inflata occurs in Core 1, 2, and 3 indicating temperate cold water. The boundary between upper Pliocene and Quaternary was tentatively drawn above the level of extinction of Globigerinoides obliquus which occurs at Sample 5-1, $124 \mathrm{~cm}$. Core 4 had a very poor recovery and was not sampled. In the interval from Cores 1 to 3, some shallow water forms were recorded, for example, Hyalinea balthica.

\section{Quaternary (Hole 378A)}

Core 1 is Quaternary in age. Globorotalia truncatulinoides was recorded in Sections 1 and 4 and Globorotalia inflata is present in all the samples processed.

Core 2 had a very poor recovery and was not sampled.

\section{Pliocene (Hole 378)}

Samples from Cores 5 and 6 were tentatively placed in the upper Pliocene Globorotalia inflata Zone. Globorotalia inflata is rather rare here and occurs only in Samples 5-2, $127 \mathrm{~cm}$ and 5, CC. The first occurrence of Globorotalia pachyderma is at Sample 6, CC and the boundary between the Globorotalia inflata Zone and the Globigerinoides obliquus extremus Zone was tentatively drawn between Cores 6 and 7 .

From Samples 7-1, $100 \mathrm{~cm}$ to 8, CC, Globorotalia crassaformis and Globorotalis semiliana were successively recorded. This interval belongs in the Globigerinoides obliquus extremus Zone. Sample 9, CC is placed in the Sphaeroidinellopsis subdehiscens Zone while the interval Samples 10, CC to $11-2,120 \mathrm{~cm}$ belongs in the
Globorotalia margaritae evoluta Zone. Samples 11-4, $30 \mathrm{~cm}$ to $11, \mathrm{CC}$ belong in the Globorotalia margaritae Zone. Globigerina nepenthes becomes extinct at Sample $11-4,144 \mathrm{~cm}$.

\section{Pliocene (Hole 378A)}

The interval spanning Samples 3-0, $122 \mathrm{~cm}$ to $3-6$, $120 \mathrm{~cm}$ belongs to the Globorotalia margaritae evoluta Zone, while that spanning Samples 3-6, $148 \mathrm{~cm}$ to 4-1, $4 \mathrm{~cm}$ is placed in the Globorotalia margaritae Zone.

\section{Benthic Foraminifers}

The upper Pliocene and Pleistocene benthic foraminiferal fauna in both holes is rich, diverse, and consists of normal-sized specimens in contrast to the smaller specimens of the other sites. The fauna reflects an upper mesobathyal habitat $(>1000 \mathrm{~m})$ and consists of Articulina tubulosa, Astrononion umbilicatulum, Cibicides kullenbergi, C. wuellerstarfi, Eponides pusillus, and Quinqueloculina venusta. In the lower part of the section and in the lower Pliocene sequence there is a marked increase in abundance of a lower epibathyal (>500-700 m) fauna (i.e., Bulimina alazanensis, Chilostomella spp., Cibicides bradyi, Epistominella exigua, E. rugosa convexa, Eponides umbonatus, Gyroidina soldanii, Pullenia bulloides and P. quingueloba).. The lowest Pliocene sequence here appears to be faunally the shallowest Pliocene $(>500 \mathrm{~m})$ found at any of the Mediterranean sites.

The Messinian sequence in Hole $378 \mathrm{~A}(4, \mathrm{CC})$ is barren of benthic foraminifers.

\section{SEDIMENTATION RATES}

Levels of zonal boundaries determined or interpolated in Holes 378 and 378 A are plotted in Figure 11 against an absolute time scale derived from the sequence of magnetic reversals (Ryan et al., 1974). A number of boundary depths appear well defined: (1) a Pleistocene/Pliocene boundary at between 112 and 138 meters subbottom, (2) an MPl-5/MPl-4 boundary within the late Pliocene at around 250 meters subbottom; (3) a late/early Pliocene boundary (MPl-4/MPl3) at about 280 meters subbottom; (4) An MPI$3 / \mathrm{MPl}-2$ boundary within the early Pliocene at around 307 meters subbottom; (5) the Pliocene (MPl-2)/ Miocene (uppermost Messinian) unconformable contact at 308 meters subbottom, which is supported by both seismic and drilling evidence.

The graph allows the definition of sedimentation rates of at least $0.9 \mathrm{~cm} / 10^{3} \mathrm{yr}$ for the early Pliocene, $9.6 \mathrm{~cm} / 10^{3} \mathrm{yr}$ for the late Pliocene, and $7.7 \mathrm{~cm} / 10^{3} \mathrm{yr}$ for the Quaternary.

The mean rate quoted above for the Quaternary is probably an underestimation since a major unconformity is discernible on the seismic records at around 98 meters subbottom. This would locate it within Core 2 of Hole 378. No immediate change in lithology was noted here and the biostratigraphy is capable of assigning ages of N22 and NN19 only, a resolution to within a time range spanning $1.3 \mathrm{~m}$.y. This means that rates of deposition within the Quaternary were at least 


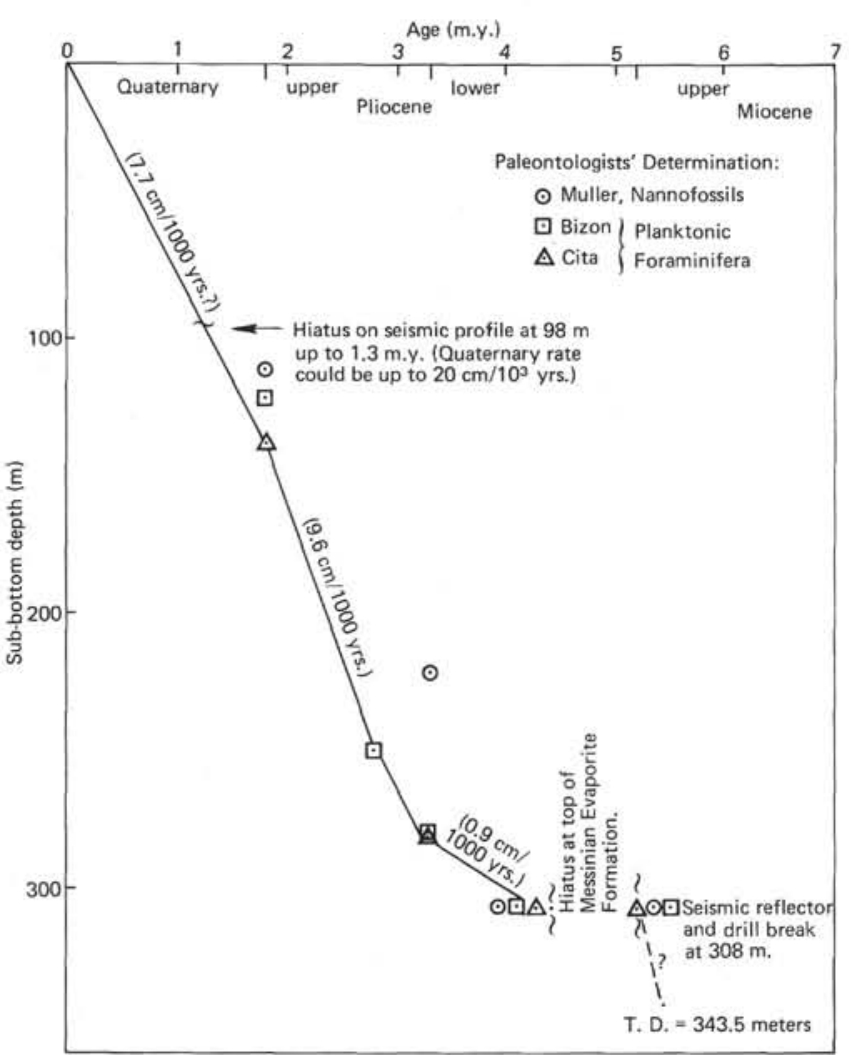

Figure 11. Sedimentation rates at Site 378.

$15 \mathrm{~cm} / 10^{3} \mathrm{yr}$ (Cita) and could have reached as much as $20 \mathrm{~cm} / 10^{3} \mathrm{yr}$.

The striking increase in sedimentation rates from the early to late Pliocene, $0.9 \mathrm{~cm} / 10^{3} \mathrm{yr}$ to $9.6 \mathrm{~cm} / 10^{3} \mathrm{yr}$ must represent a major change in conditions of sediment dispersal within the Cretan Basin over this period.

\section{CORRELATION OF SEISMIC REFLECTION PROFILES WITH DRILLING RESULTS}

Site 378 was located on "Meteor" 33 Profile 13 to the north of Heraklion, on the northern flank of a small "central depression" within the north Cretan Basin. Two main reflectors can be observed on the profile separating two seismic units (see Figure 12):

1) from the sea bottom to reflector 1 , a sedimentary sequence with numerous horizontal reflectors infilling a depression ("ponded facies"). This depression is $360 \mathrm{msec}$ (two-way travel time) thick in the axis of the "pond" and only 125-130 msec (two-way travel time) on the flanks, where the hole was located; and

2) from reflector 1 to reflector 2 , a more transparent sequence within the two major reflections ("transparent facies"').

No reflections can be recognized below reflector 2 at 260-270 msec (two-way travel time) because this is marked by numerous diffractions.

The "Meteor" profile is a multichannel record and no interval velocity was provided. The dating of reflector 1 was one of the objectives of drilling Site 378, but no obvious lithological change was recorded be- tween Cores 1 and 5 where it was expected to be located.

Velocity measurements made on the cores (see Physical Properties Section) are thus used for correlation (Table 5). In general, very low velocities have been measured in the Pliocene to Quaternary section.

Core 1, Hole 378 and Core 1, Hole 378A show mean values between $1.525 \mathrm{~km} / \mathrm{sec}$ and $1.533 \mathrm{~km} / \mathrm{sec}$. From Core 2, Hole 378 downhole, the velocities are slightly higher (more than $1.56 \mathrm{~km} / \mathrm{sec}$ ). Using 1.53 $\mathrm{km} / \mathrm{sec}$ for calculation, we obtain 98 meters for the thickness of the upper unit. Even if a velocity of 1.55 $\mathrm{km} / \mathrm{sec}$ is used, the thickness does not exceed 100 meters.

Reflector 1, corresponding to a structural event which deformed the underlying sequence and created the small central depression, might be related to the abrupt change in the paleo-depth recorded by the benthic foraminiferal assemblages between Cores 1 and 2 of Hole 378.

Using a mean velocity of $1.6 \mathrm{~km} / \mathrm{sec}$ for the interval between reflectors 1 and 2 (values are from $1.56 \mathrm{~km}$ / sec in Core 2 to $1.64 \mathrm{~km} / \mathrm{sec}$ in Core 8), a thickness of about 210 meters is obtained. Thus the depth of reflector 2 is at about 308 meters subbottom. This is in excellent agreement with the depth of the Messinian evaporites recorded at 308 meters subbottom in Holes 378 and $378 \mathrm{~A}$.

Reflector 2 here has been referred to as "event A" by German marine geologists. We conclude that "event A" is equivalent to "horizon $\mathrm{M}$ " of the other Mediterranean Basins, that is the top of the Mediterranean evaporite formation.

TABLE 5

Velocity Determinations, Site 378

\begin{tabular}{lcccr}
\hline & $\begin{array}{c}\text { Velocity } \\
\text { Travel Time } \\
(\mathrm{msec})\end{array}$ & $\begin{array}{c}\text { Measurements } \\
\text { Made on } \\
\text { Cores } \\
(\mathrm{km} / \mathrm{sec})\end{array}$ & $\begin{array}{c}\text { Thickness } \\
\text { from } \\
\text { Velocity } \\
(\mathrm{m})\end{array}$ & $\begin{array}{c}\text { Depth } \\
\text { from } \\
\text { Drilling } \\
(\mathrm{m})\end{array}$ \\
\hline Sea bottom & 0 & 1.53 & 98 & 0 \\
Seismic reflector 1 & $125-130$ & 1.6 & 210 & 98 \\
Seismic reflector 2 & $260-270$ & & & 308 \\
\hline
\end{tabular}

\section{SUMMARY AND CONCLUSIONS}

Holes 378 and 378A were located on the northern flank of a small depression in the north Cretan Basin of the Aegean Sea. Its coordinates were $35^{\circ} 55.67^{\prime} \mathrm{N}$ and $25^{\circ} 06.97^{\prime} \mathrm{E}$, in a water depth of 1835 meters below sea level. The location was chosen from a "Meteor" 33 seismic profile which showed two main seismic sequences separated by prominent reflectors. The upper is a sequence of horizontal "ponded" layers infilling a depression and these are underlain by a deformed lower unit.

Our primary objectives were (1) to investigate the end of the Messinian evaporite deposition and its transition to normal marine conditions, (2) to determine the paleooceanography of the Pliocene-Quater- 


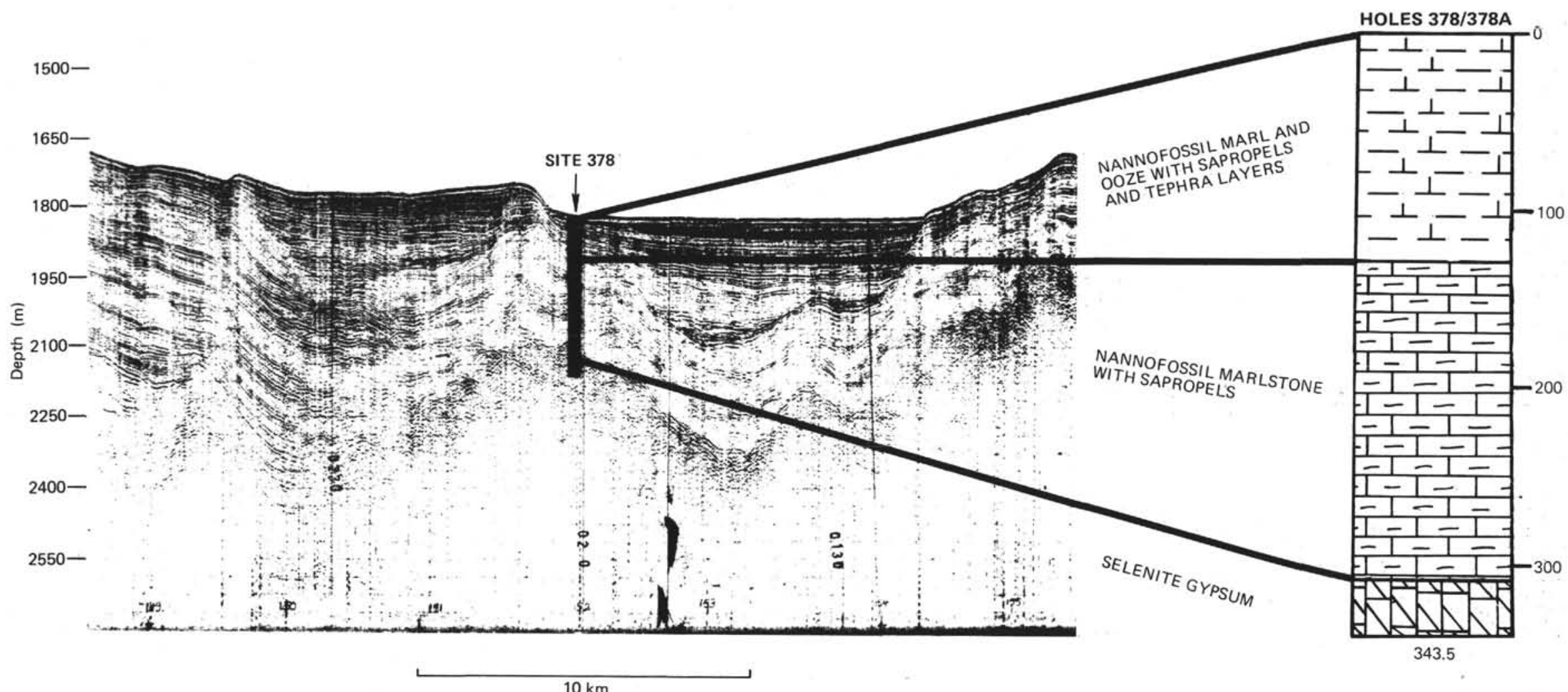

Figure 12. Correlation of BGR/"Meteor" 33 profile 13 with drilling results at Site 378. 
nary in the Aegean Sea, and (3) to establish the age of the last deformation of the sediments in this "back arc" basin.

Two holes were drilled at the same location to complete these objectives. The section penetrated can be broadly subdivided into four lithologic units.

Unit 1 consists of hemipelagic nannofossil marls and oozes of Quaternary age, 132 meters thick. They are dark gray in color and contain numerous intercalated sapropels and sapropelic layers. Unexpectedly no definite tephra layers have been encountered, but volcanic glass fragments are present and are particularly well represented in Core 5. Planktonic and benthic foraminifera and nannoplankton assemblages are rich and well preserved. They constitute $30 \%$ to $50 \%$ of the sediments. The sedimentation rate was very high (up to $200 \mathrm{~m} / \mathrm{m}$.y.) with indications of possible hiatuses at the base of the unit and in its middle part.

Seismic evidence suggests that the "ponded facies," which is 200 to 300 meters thick in the central depression of the Cretan Basin, should be less than 100 meters thick here. We encountered, however, no change in lithology across the unconformity. The upper part of the Quaternary hemipelagic sediment sequence here apparently is a basin-flank facies synchronous with the deposition of the "ponded facies" (turbidites) in the central depression. The intra-Quaternary unconformity, recognized on the seismic profile and dated biostratigraphically, signifies a tectonic event in the early to middle Quaternary, probably during the time represented by the late part of nannofossil Zone NN10.

Unit 2 consists of firm, gray, nannofossil marlstones of late Pliocene age. Dark sapropels and sapropelic layers are common and burrowing is moderate to intense. The composition, depositional setting, and sedimentation rate are similar to Unit 1; the main difference being related to diagenesis. The Pliocene sediments are compacted and cemented locally. The planktonic: benthic foraminifer ratio is high and the benthic species indicate a deposition in water depths greater than 1000 meters.

Unit 3 consists of early Pliocene gray nannofossil marlstones with very frequent organic-rich sapropels and sapropelic layers. These sapropelic marls have numerous burrows of varying sizes. The composition of the unit is very similar to Unit 2, but the sedimentation rate $\left(0.9\right.$ to $2.0 \mathrm{~cm} / 10^{3} \mathrm{yr}$ ) is only one-tenth that of the upper units. Paleobathymetric analysis of benthic foraminiferal assemblages indicates basin depths greater than 500 meters.

Unit 4 consists mainly of very coarse, yellowish selenitic gypsum overlain by a brecciated and vuggy dolomitic limestone.

\section{Origin of the Evaporites}

The presence of selenitic gypsum here indicates that the Aegean Basin was a part of the Mediterranean that was subjected to the Messinian salinity crisis. However, the "Lago Mare" facies, with its characteristic dolomitic-marl lithology and Cyprideis fauna, is not present above the gypsum at this site despite the proximity of the Aegean to the Paratethys. The Messinian Aegean had no connection to the Black Sea. ${ }^{2}$ Support for this conclusion comes from the results of Leg 42B drilling in the Black Sea (Hsü, in press). If the Paratethys was the source of fresh or brackish water to the Mediterranean Lago Mare, the connection ("waterfall") must have been elsewhere other than the Dardanelles. We might speculate that this opening may have been on the Adriatic Coast. The Cyprideis fauna is known from the Thessalonika Basin. Whether it had communication with the Cretan Basin is a problem to be resolved.

The selenitic gypsum was deposited in a shallow subaqueous environment (Garrison et al., this volume). The vuggy carbonate shows textures typical of subaerial diagenesis. Yet during the early Pliocene (MPl-2) the Aegean Sea was already at least 500 meters deep, suggesting a relatively sudden flooding of a partially desiccated Cretan Basin. There has certainly been PlioQuaternary subsidence of this basin behind the Hellenic Arc during the Plio-Quaternary. This continued subsidence is probably related to subduction under the Arc, an interpretation formulated on the basis of geophysical evidence (Papazachos and Comninakis, 1971). This is supported by the results of Leg 13 drilling (Hsü and Ryan, 1973), and reinforced by geothermal evidence (see below).

\section{Heat Flow}

Three down-hole temperature measurements were made at Site 378 between 122.0 and 302.5 meters subbottom. These data, in conjunction with shipboard thermal conductivity measurements, permit calculation of a heat-flow value of $2.19 \pm 0.25 \mu \mathrm{cal} / \mathrm{cm}^{2} \mathrm{sec}$ for this site. This value is in excellent agreement with the mean $\left(2.08 \pm 0.25 \mu \mathrm{cal} / \mathrm{cm}^{2} \mathrm{sec}\right)$ of eight conventional heatflow measurements in the central and northern Aegean Sea, but is substantially higher than range of heat-flow values ( 1.01 to $1.64 \mu \mathrm{cal} / \mathrm{cm}^{2} \mathrm{sec}$ ) measured in the southern Aegean close to Site 378 by Jongsma (1974), all of which are characterized by non-linear thermal gradients. The determinations of substantially higher heat flow using bore-hole temperature data, obtained far below the level to which seasonal bottom water temperature fluctuations can penetrate, suggests that the conventional heat-flow values from the southern Aegean have been decreased by former seasonal increases in bottom water temperature. The characterization of the entire Aegean as a region of high heat flow. supports geophysical interpretations of this area as a recently created back-arc basin which is presently

\footnotetext{
2 This hypothesis is not shared by M.B.C. She thinks instead that the absence of the "Lago Mare" facies at Site 378 has to be accounted for by the location of the drill site which was not in the center of the basin, but on the flank, that is in a position higher than the water level of the late Messinian south Aegean lake. In fact, caspi-brackish ostracode faunas are recorded at various localities around the Aegean Sea (Sissingh, 1976). This author could show that ..."the Late Miocene Paratethyan ostracodes invaded the Mediterranean through a passage way in Thracia, Turkey.
} 
being under-thrust by the eastern Mediterranean sea floor. For additional details on the heat-flow measurements at Site 378 , see Erickson and von Herzen, this volume.

\section{REFERENCES}

Biju-Duval, B., Letouzey, J., Montadert, L., Courier, P., Mugniot, J. F., and Sancho, J., 1974. Geology of the Mediterranean Sea basins. In Burk, C. and Drake, C. The geology of continental margins: (New York Springer verlag).

Ciaranfi, N. and Cita M. B., 1973. Paleonotlogical evidence of changes in the Pliocene climate. In Ryan, W. B. F., Hsü, K. J., et al., Initial Reports of the Deep Sea Drilling Project, Volume 13: Washington (U.S. Government Printing Office), p. 1387-1399.

Hsü, K. J., in press. Lacustrine sedimentation in the Black Sea and its relation to the Mediterranean. In Ross, D. C., Neprochnov, Y., et al., Initial Reports of the Deep Sea Drilling Project, Volume 42B. Washington (U.S. Government Printing Office).
Hsü, K. J. and Ryan, W. B. F., 1973. Deep-sea drilling in the Hellenic Trench: Geol. Soc. Greece, Bull. v. 10, p. 81-89.

Jongsma, D., 1974. Heat Flow in the Aegean Sea, Geophys. J. Roy. Astron. Soc., v. 37, p. 337-346.

McKenzie, D., 1972 Active tectonics of the Mediterranean region: Geophys. J. Roy. Astron. Soc., v. 30, p. 109-185.

Papazachos, B.C., and Comninakis, P.E., 1971, Geophysical and tectonic features of the Aegean Arc: J. Geophys. Res., v. 76, p. $8517-8533$.

Ryan, W. B. F., Hsü, K. J., et al., 1973. Initial Reports of the Deep Sea Drilling Project, Volume 13: Washington (U.S. Government Printing Office).

Ryan, W. B. F., Cita, M. B., Dreyfus Rawson, M., Burkle L. H., and Saito, T., 1974. A paleomagnetic assignment of Neogene stage boundaries and the development of isochronous datum planes between the Mediterranean, Pacific, and Indian oceans in order to investigate the response of the World Ocean to the Mediterranean salinity crises: Riv. Ital. Paleontol. Strat. v. 80, p. 631-688.

Sissingh, W., 1976. Aspects of the late Cenozoic evolution of the South Aegean ostracode fauna. In The biodynamic effects of the Messinian salinity crisis: Paleo geog., climatol., Eco., v. 20, p. 131-146. 


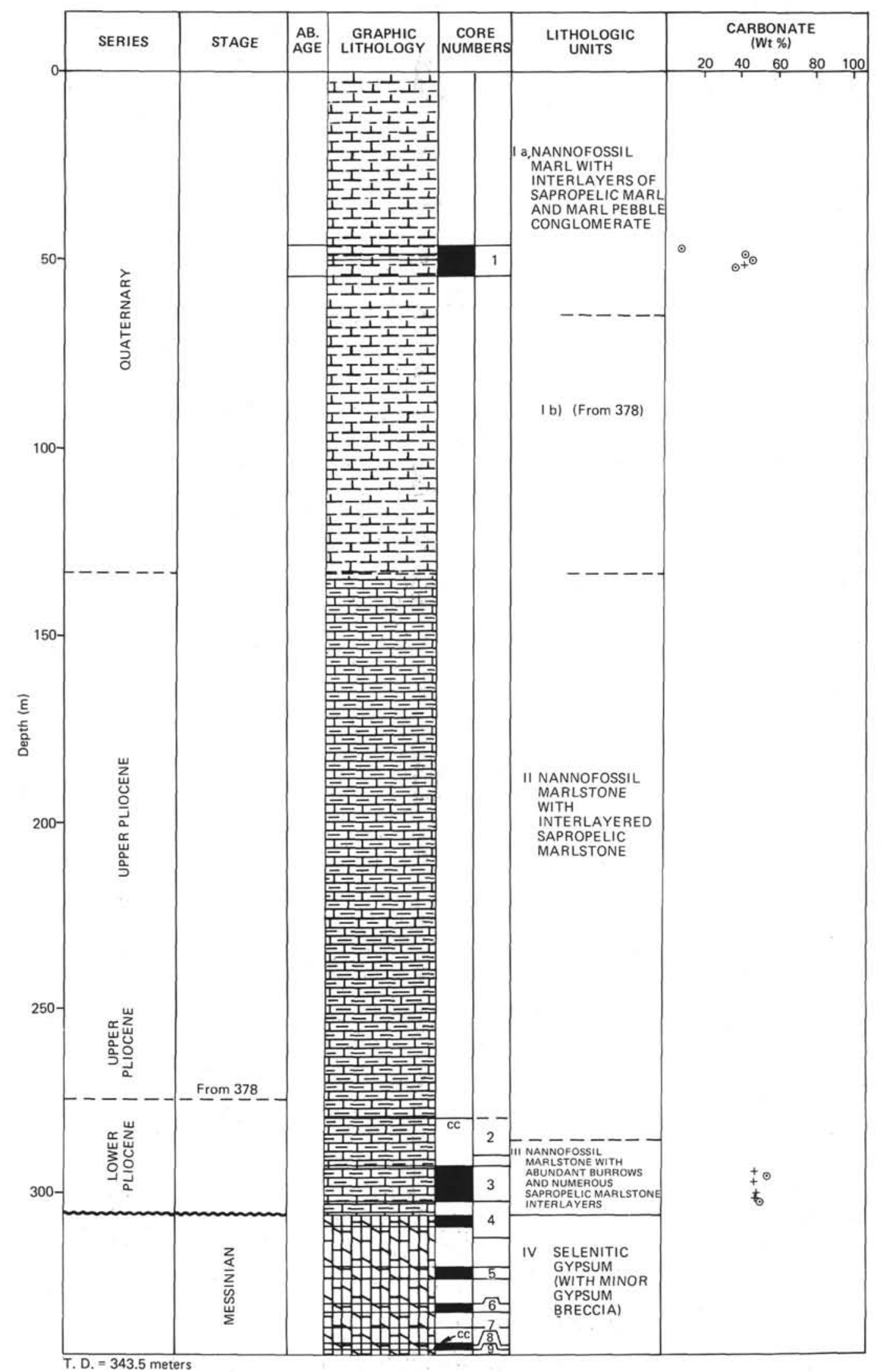




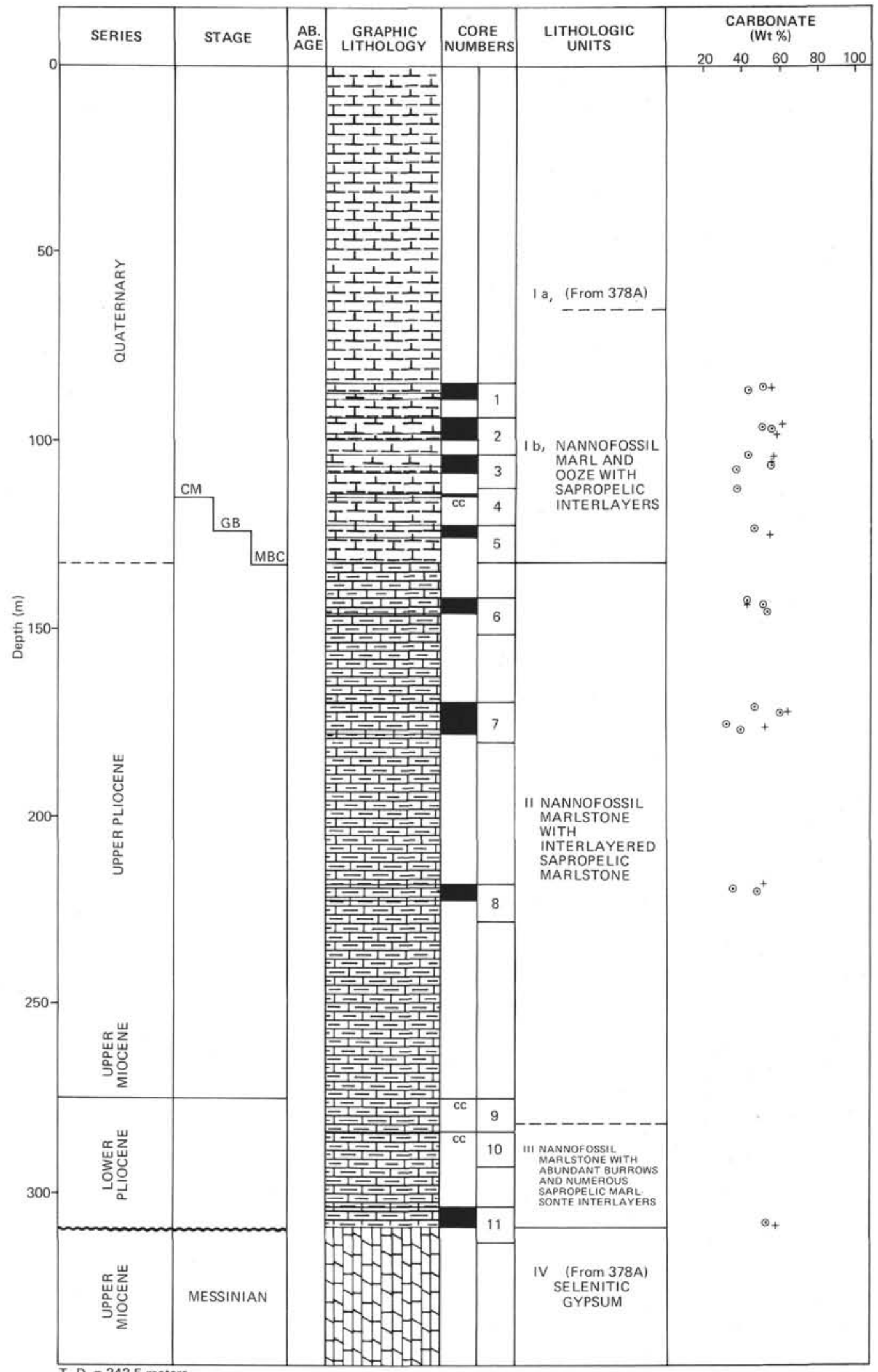




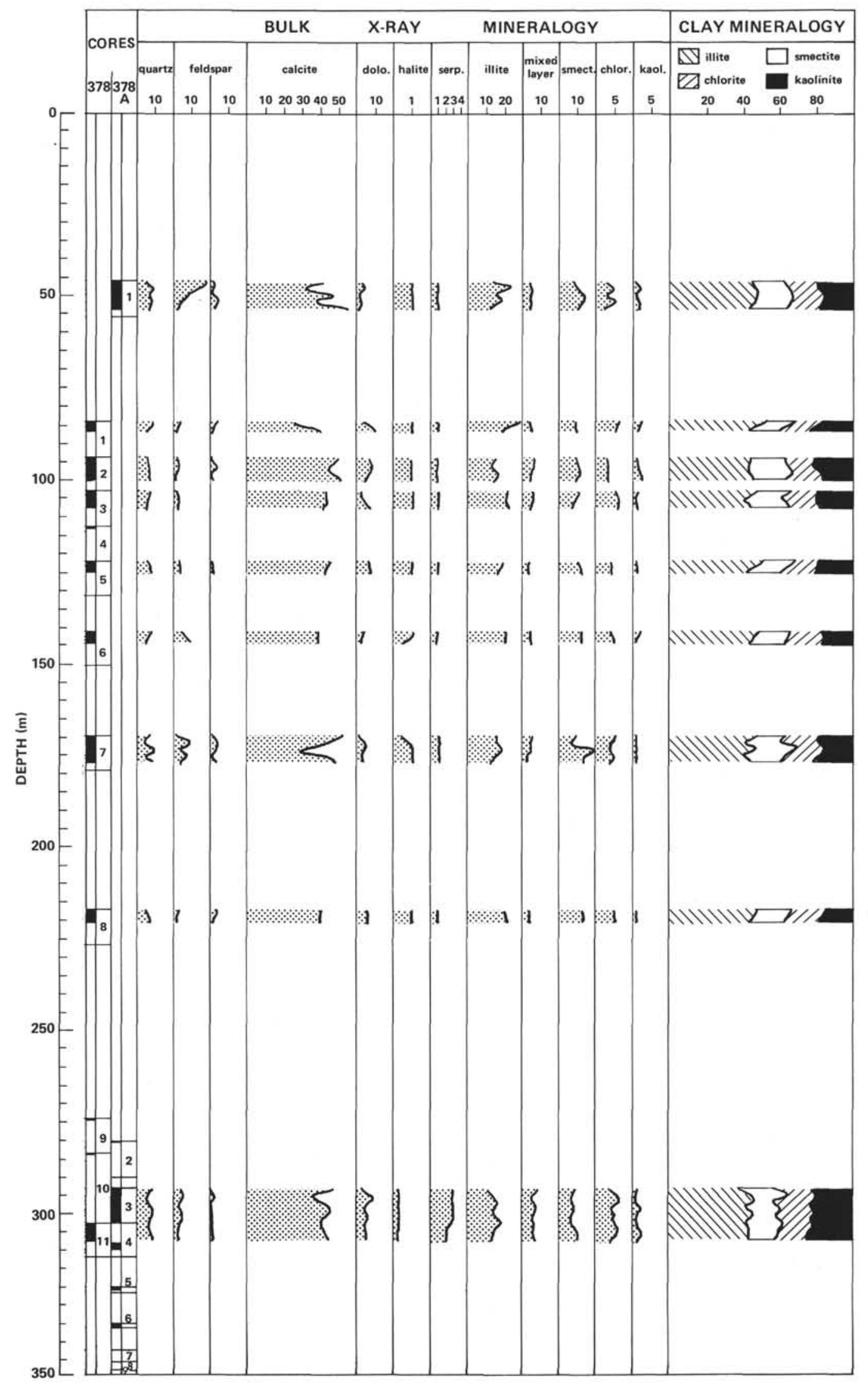

Note: X-ray mineralogy for both Holes 378 and $378 \mathrm{~A}$ are included here. 


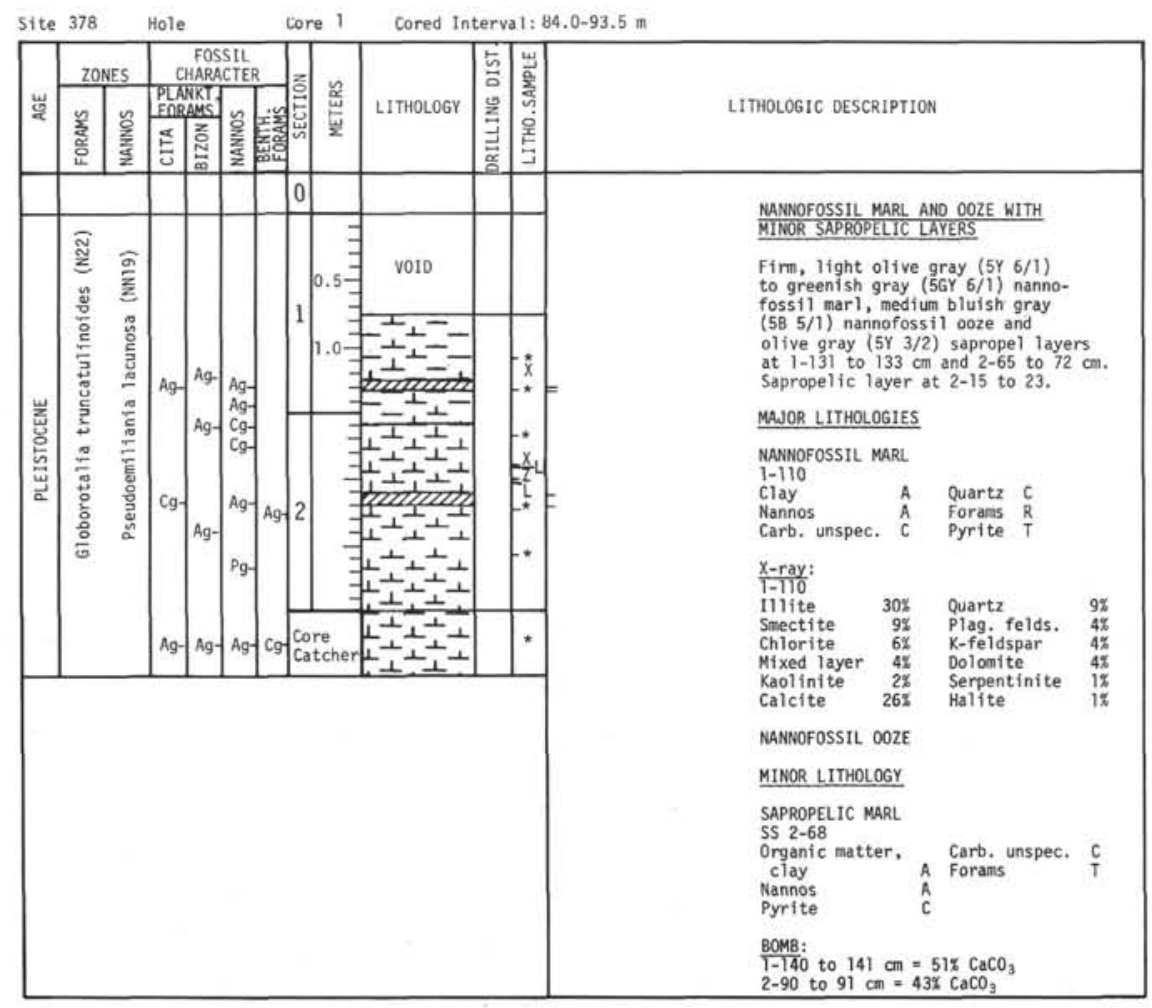

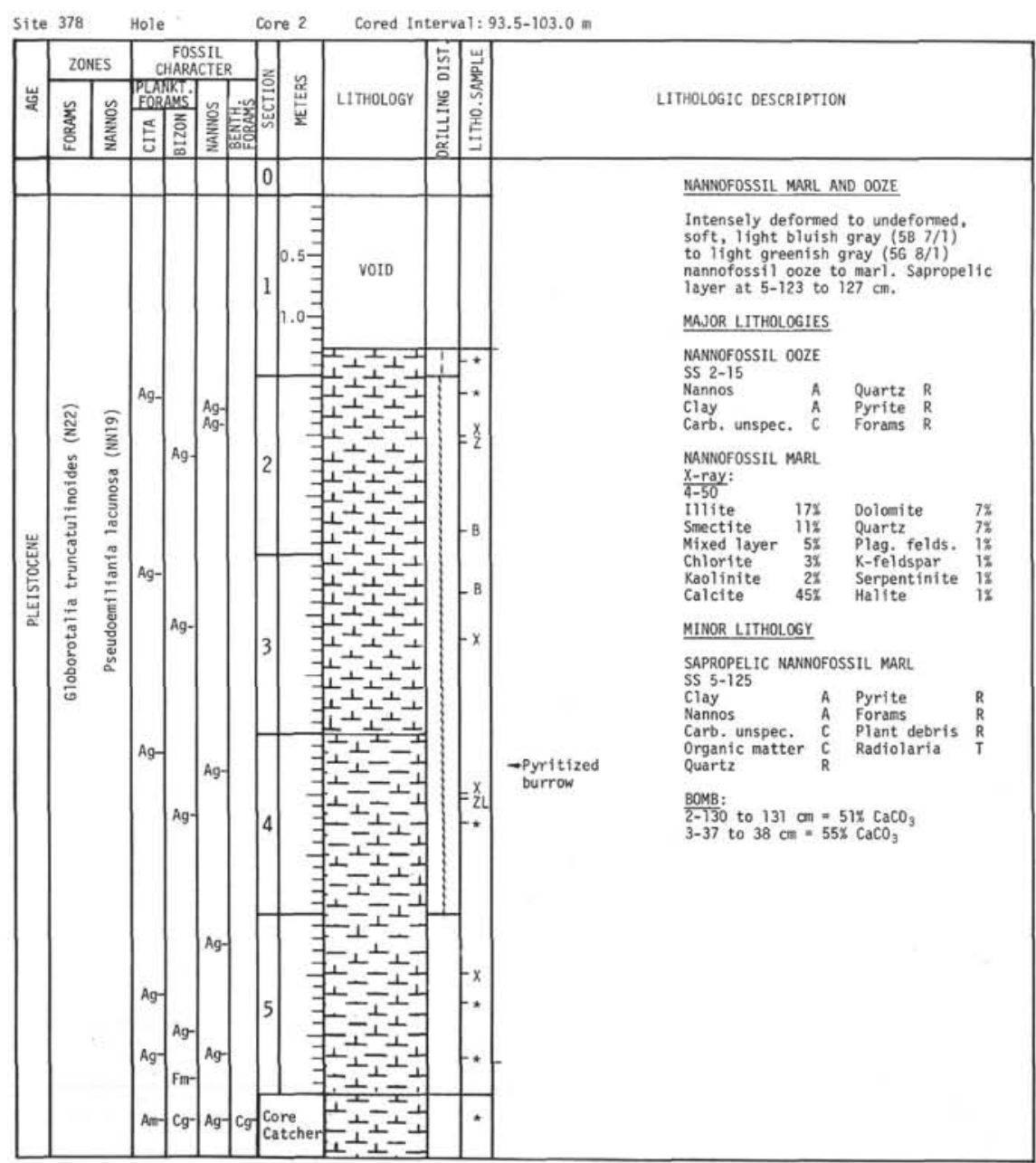




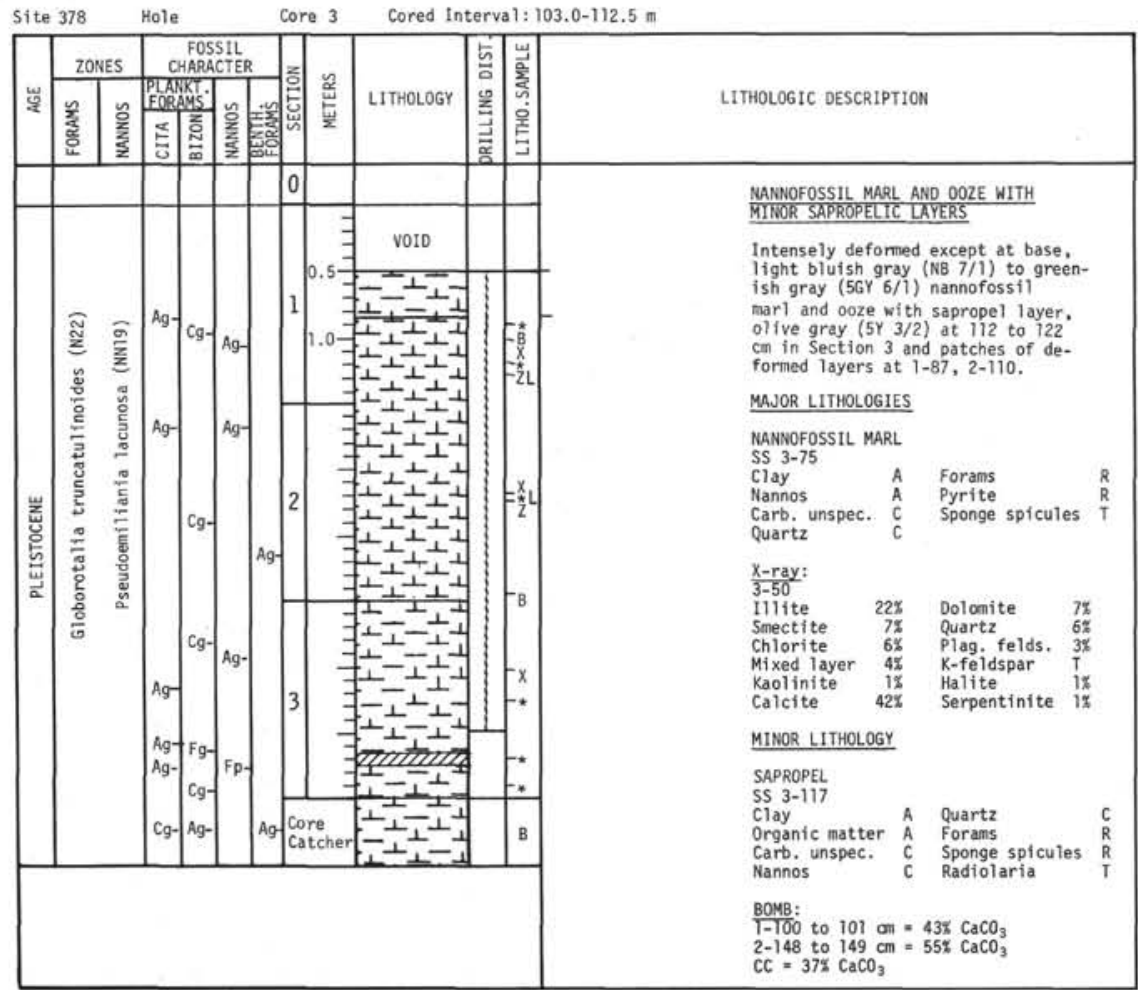

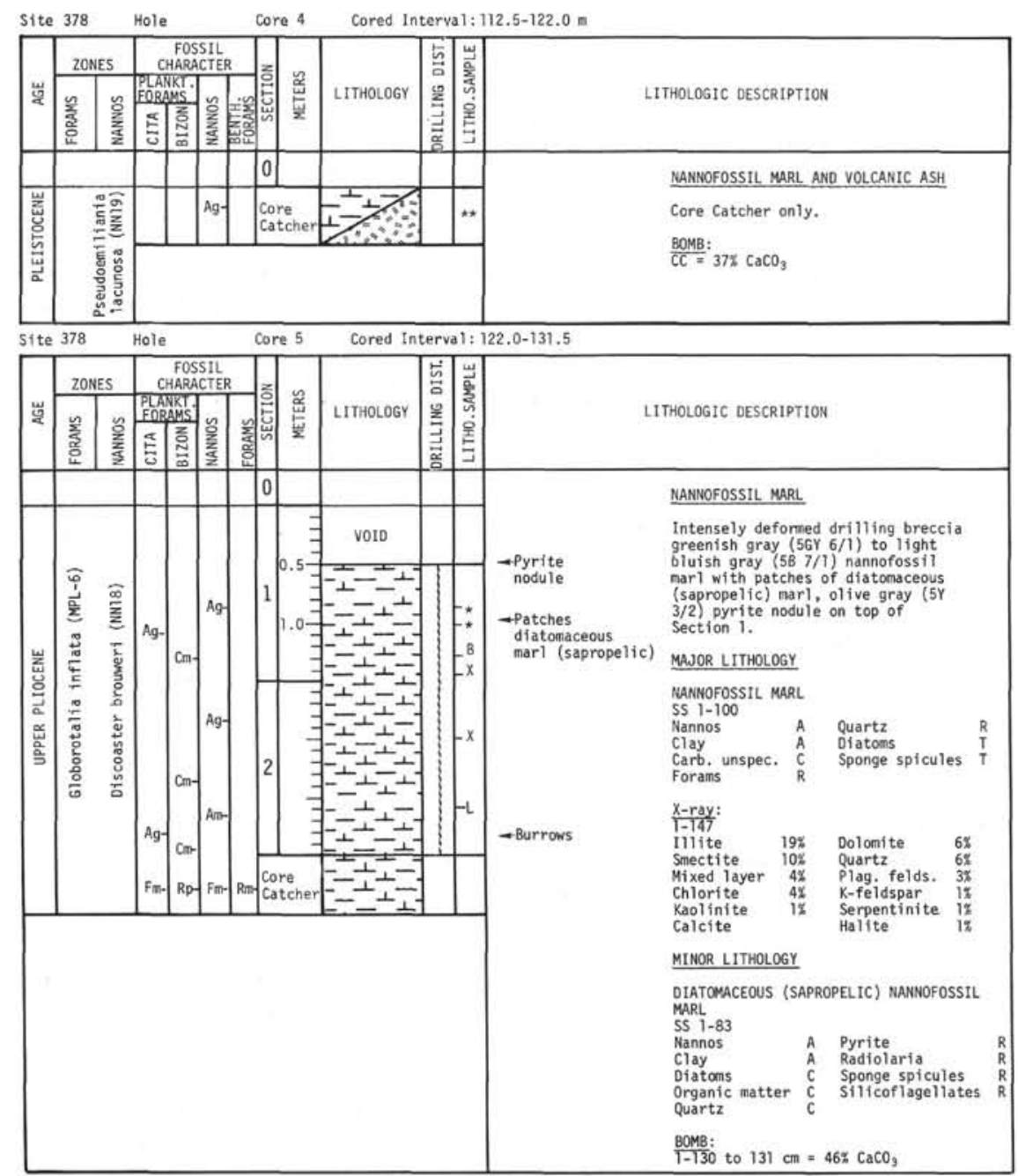




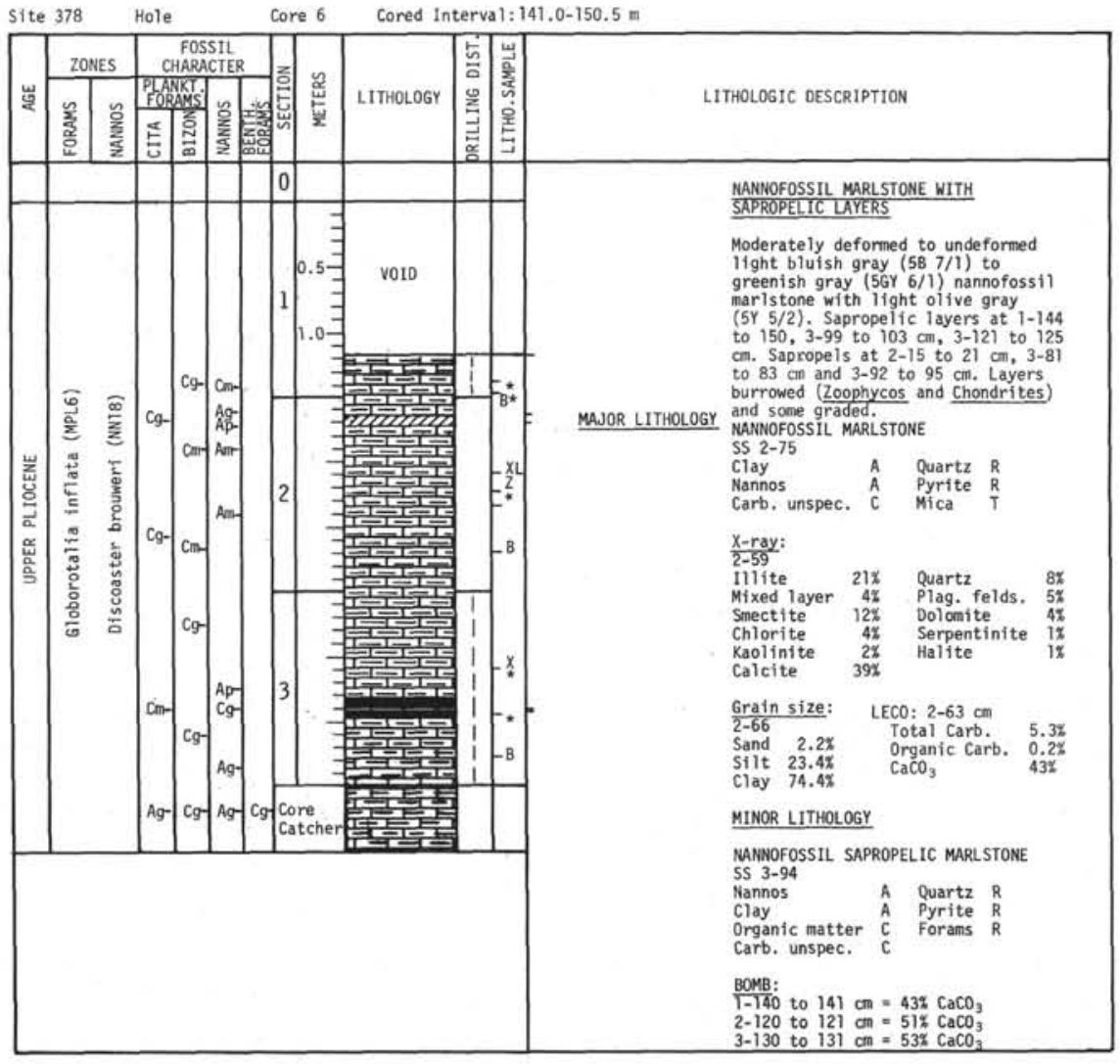

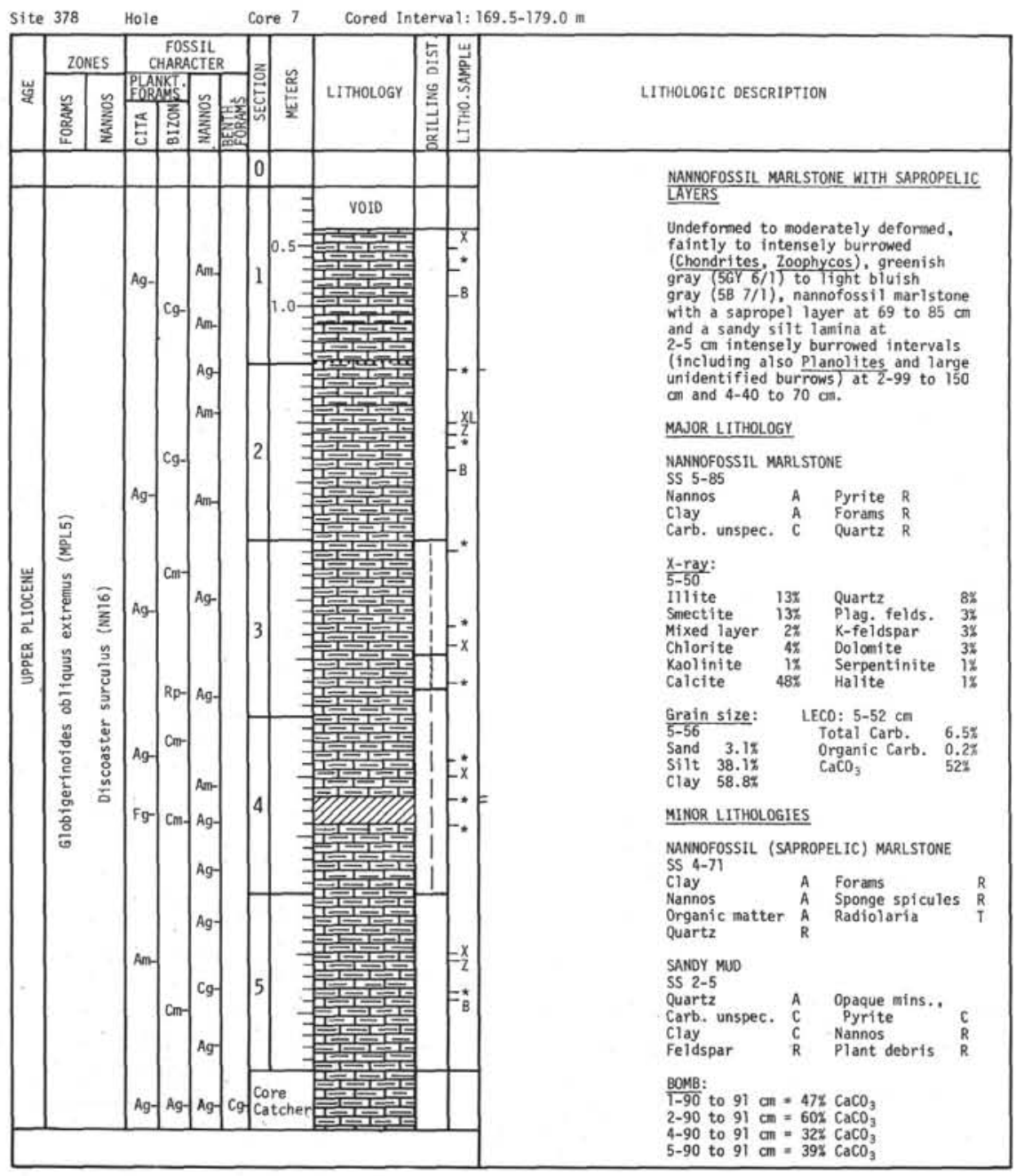




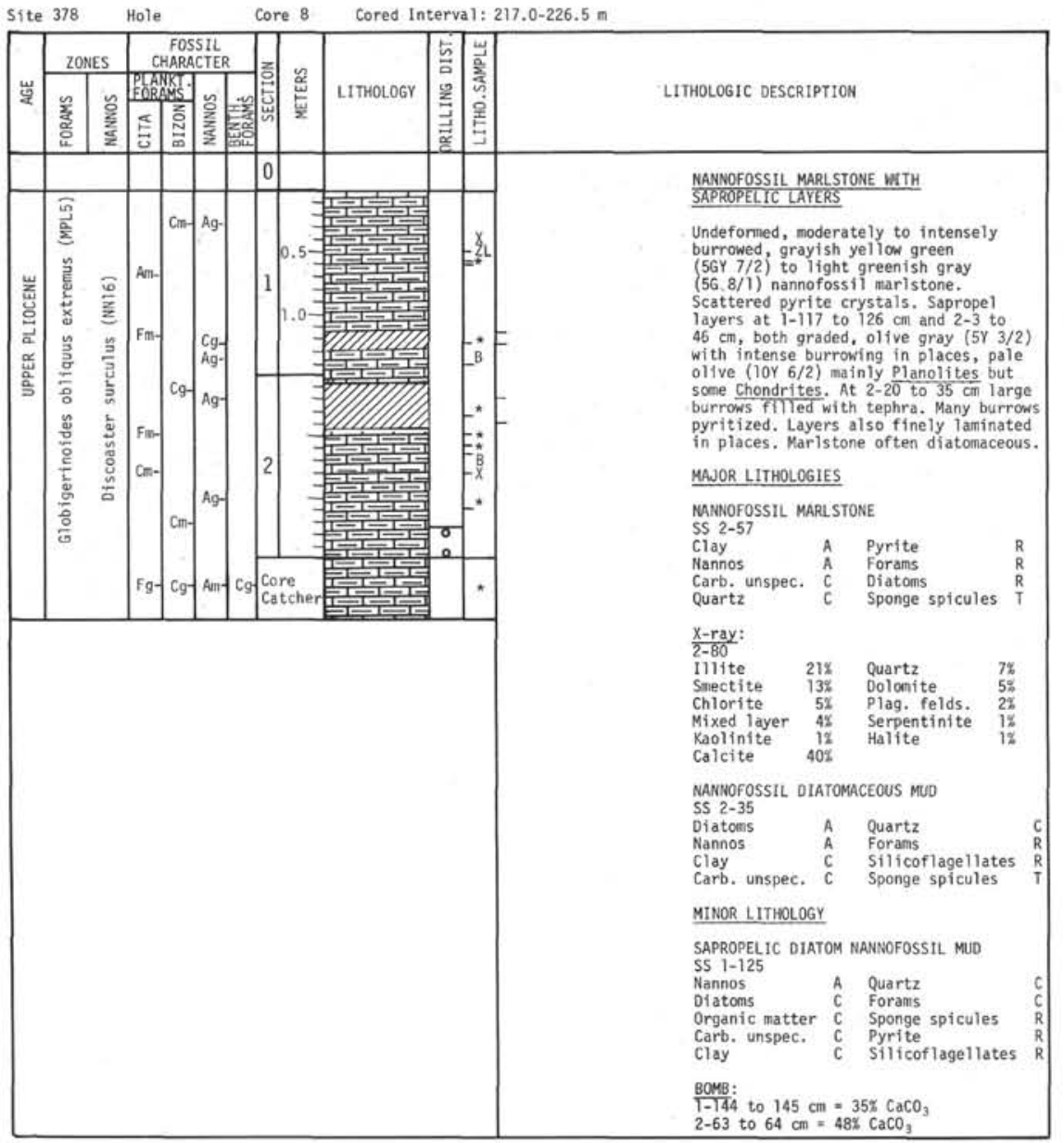

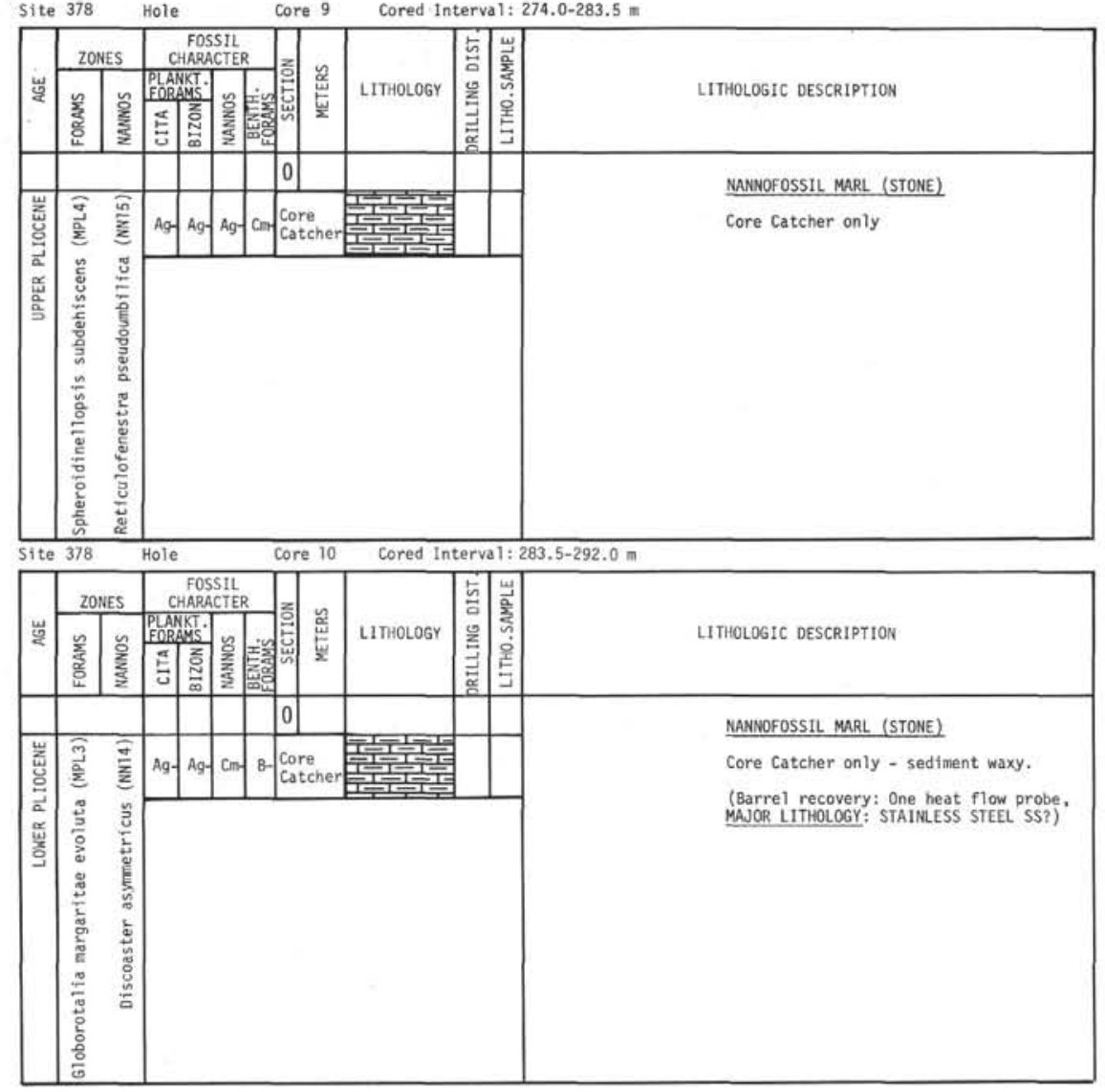



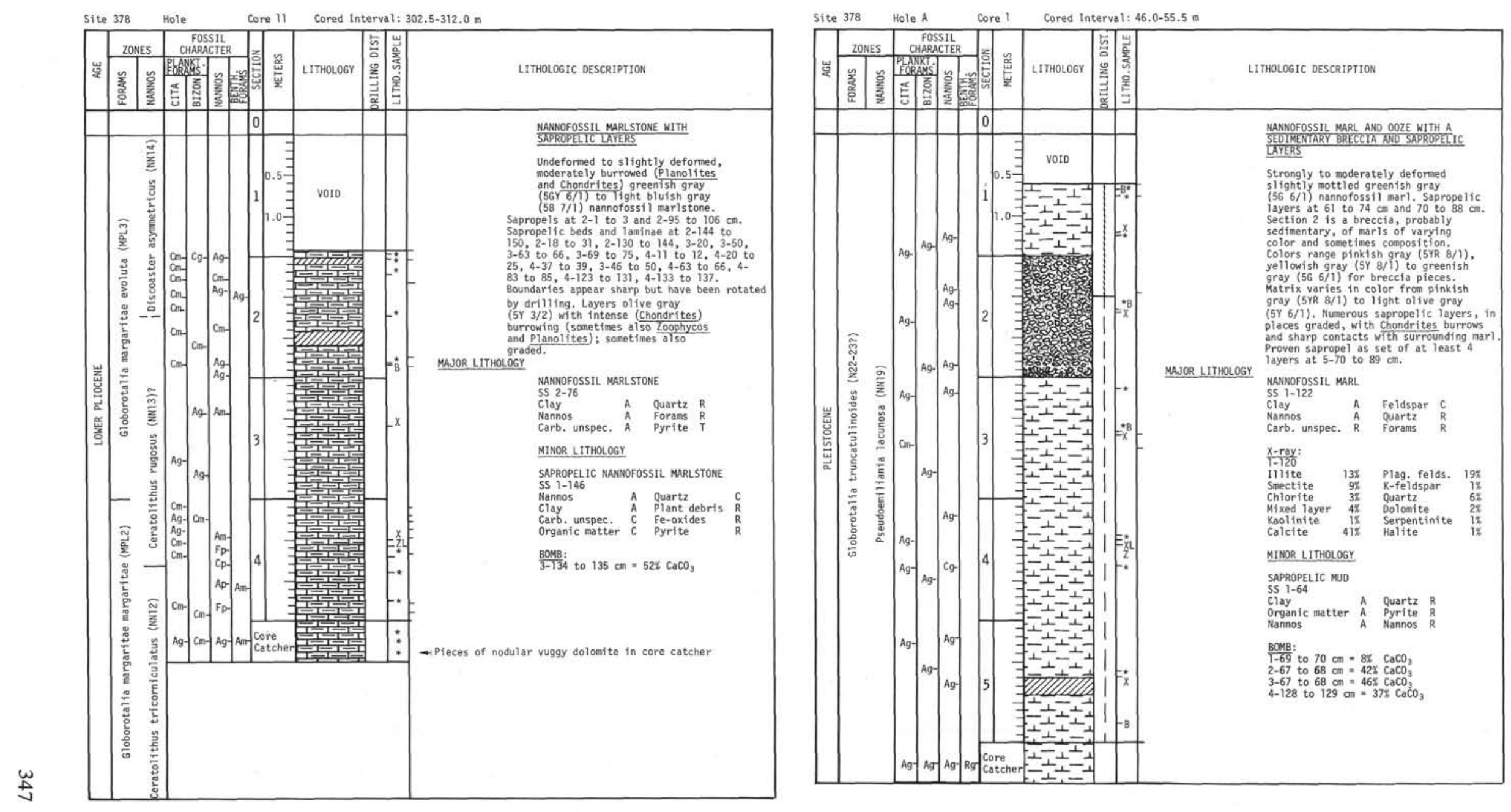


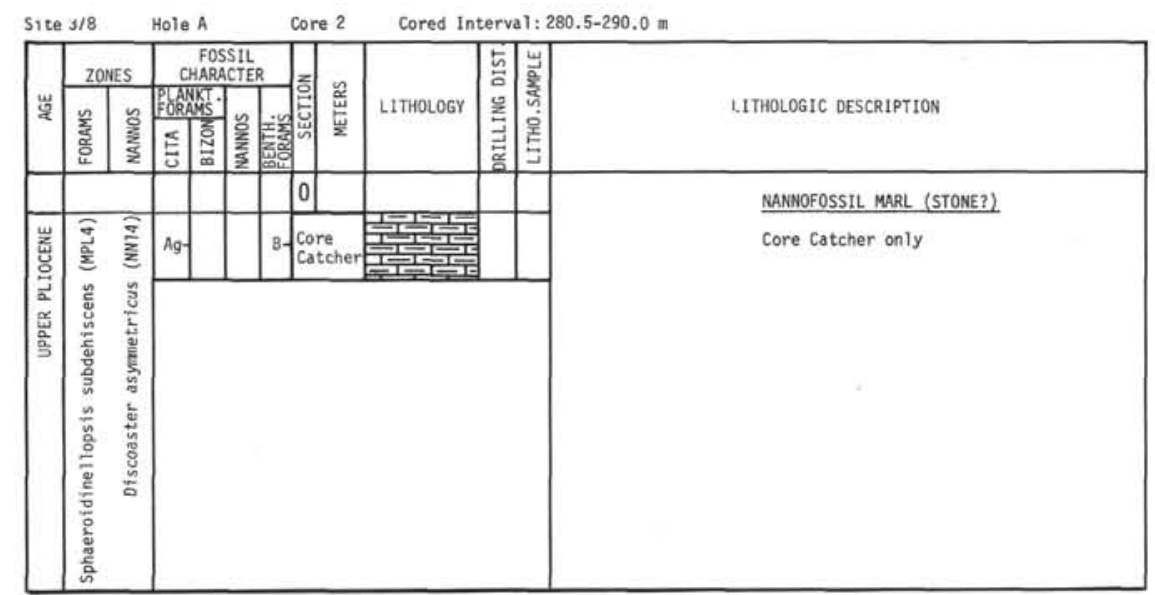

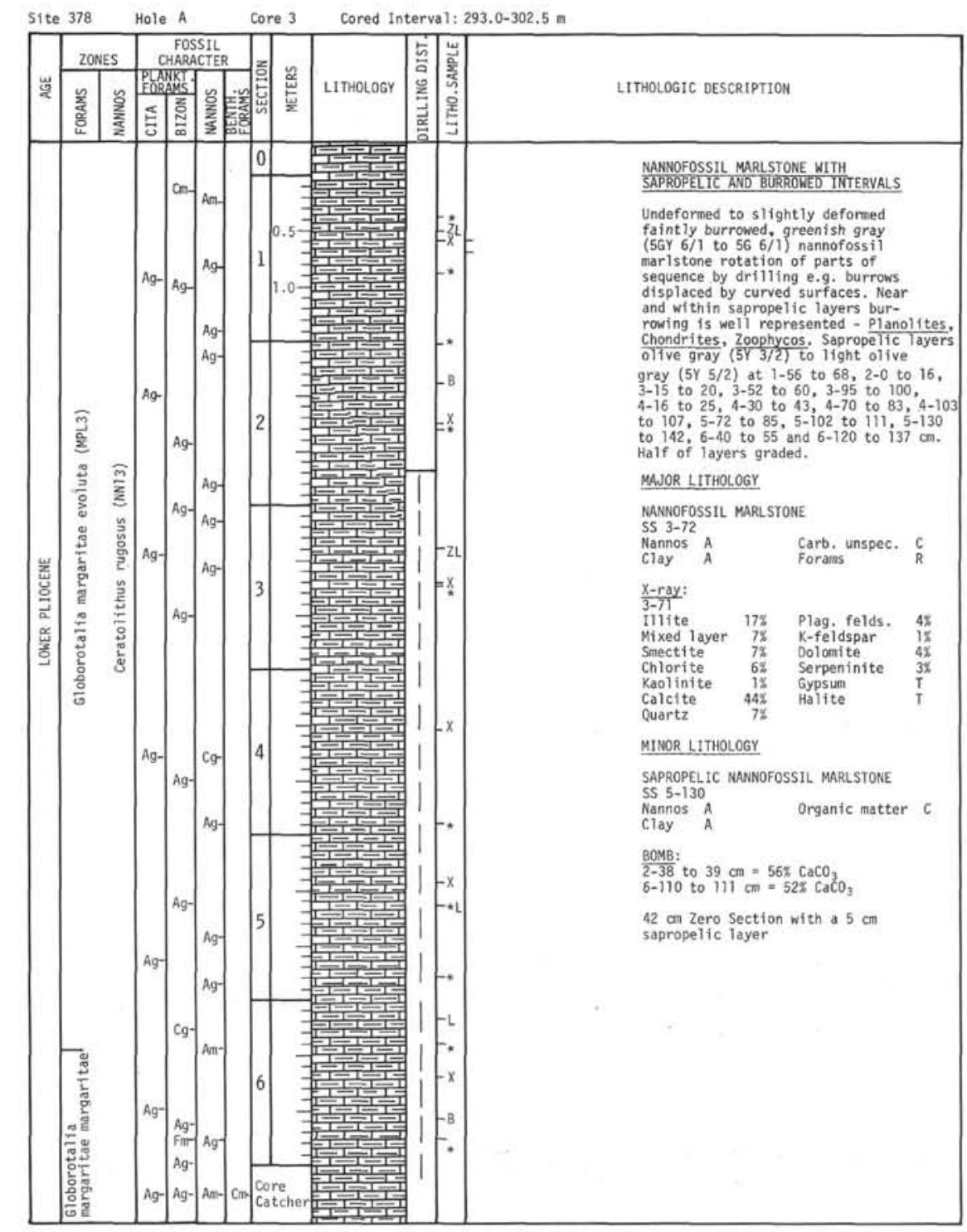



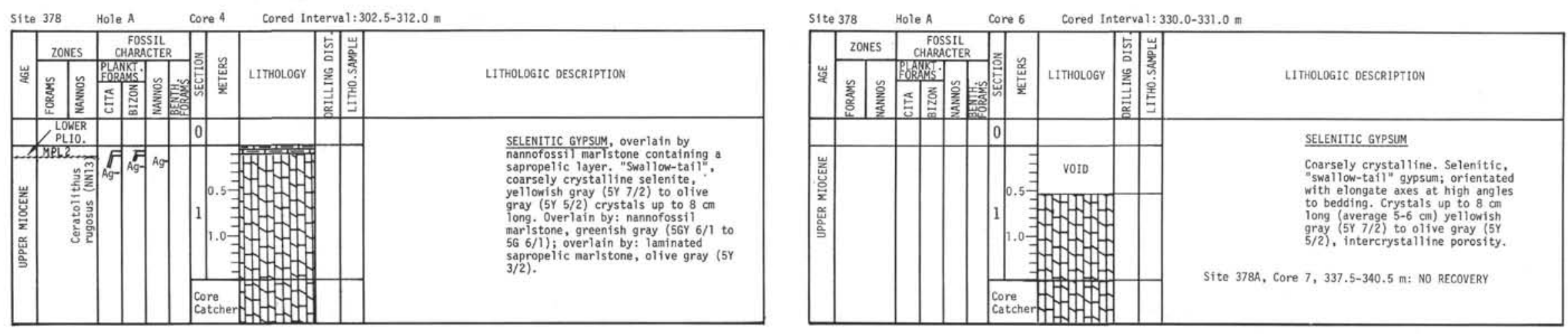

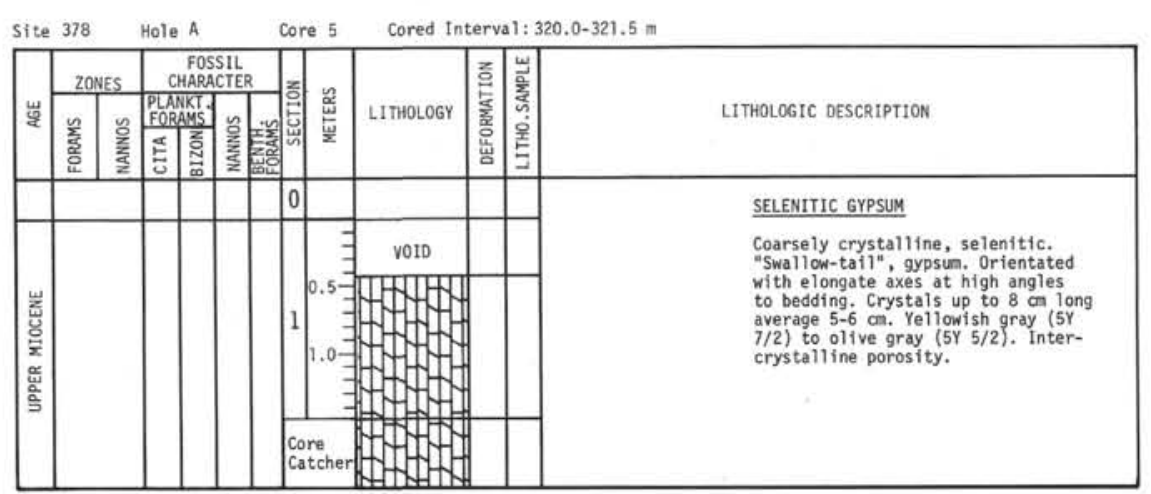

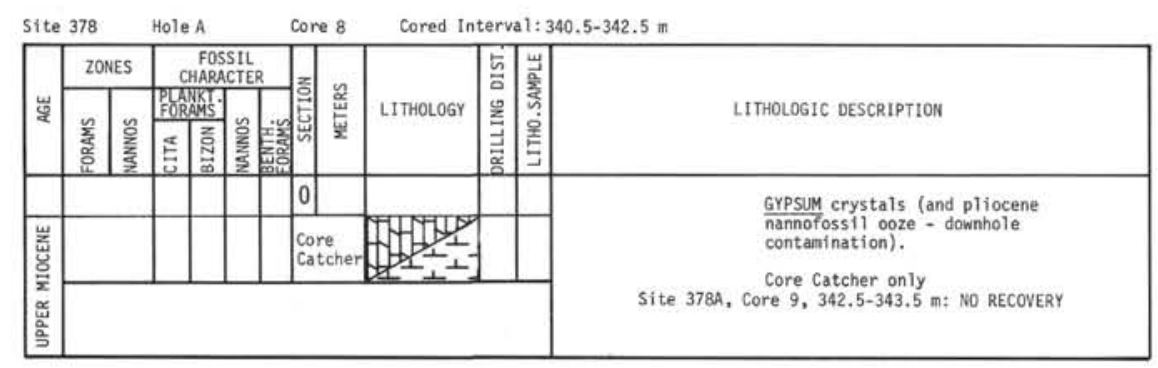




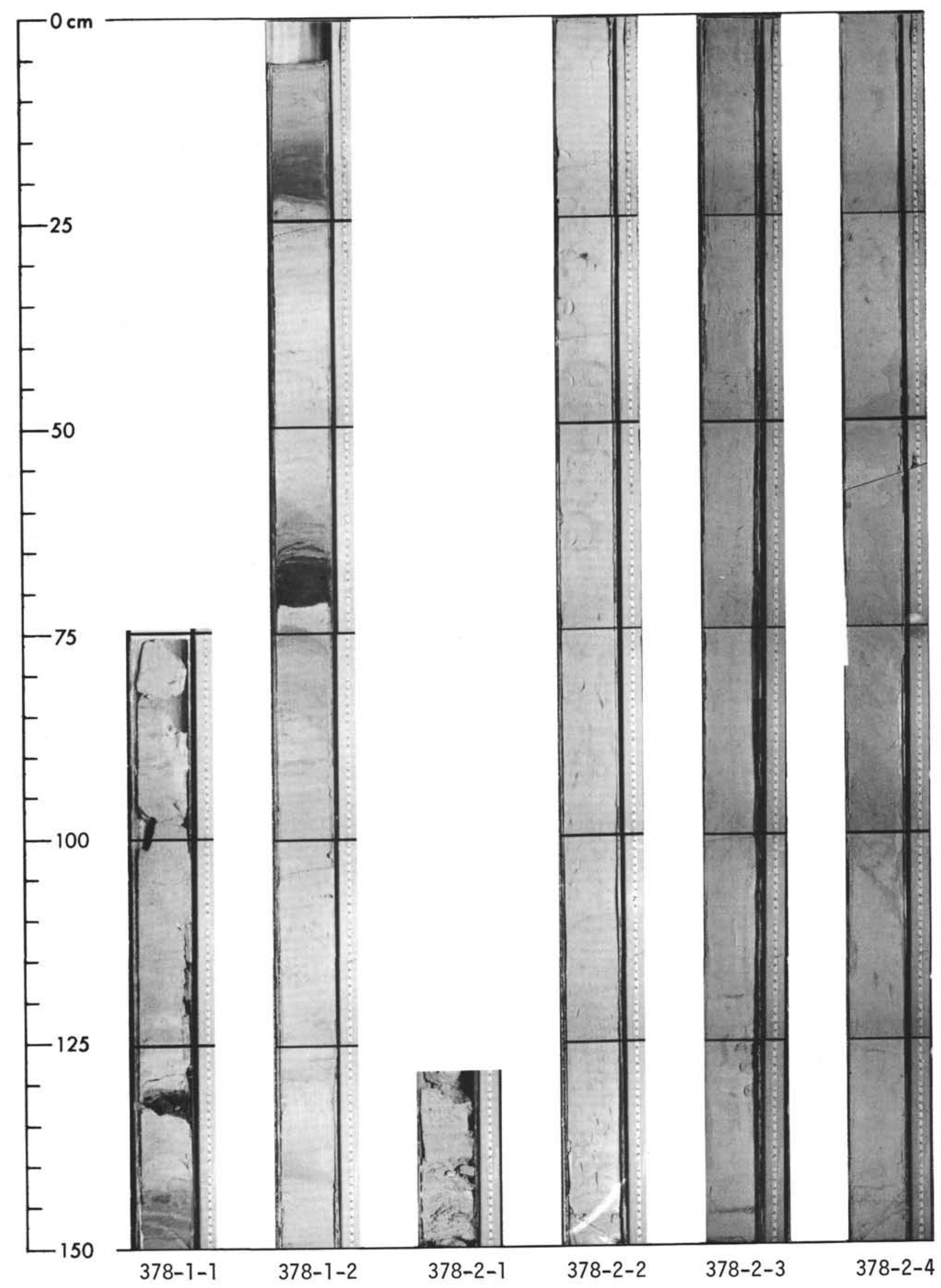




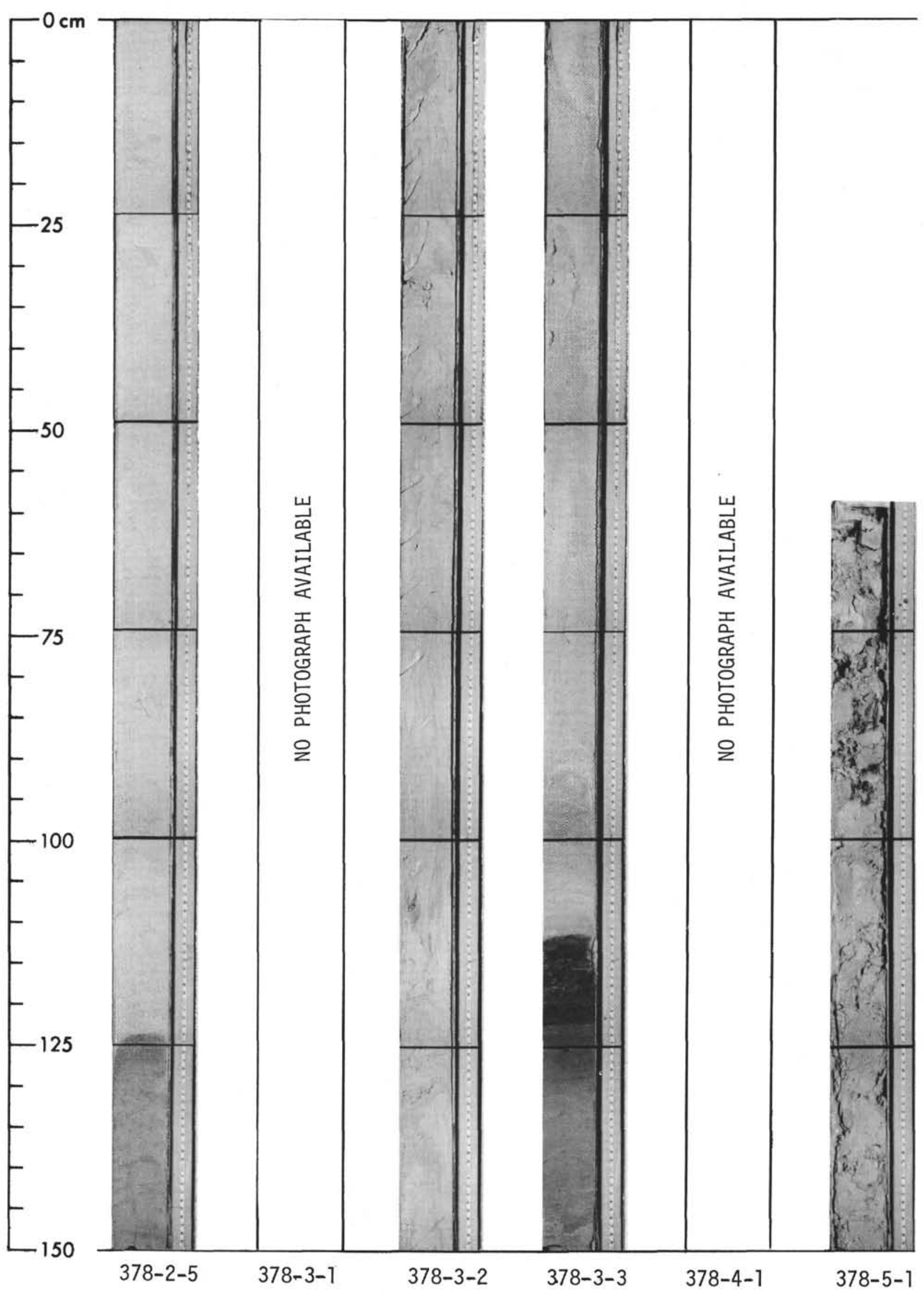




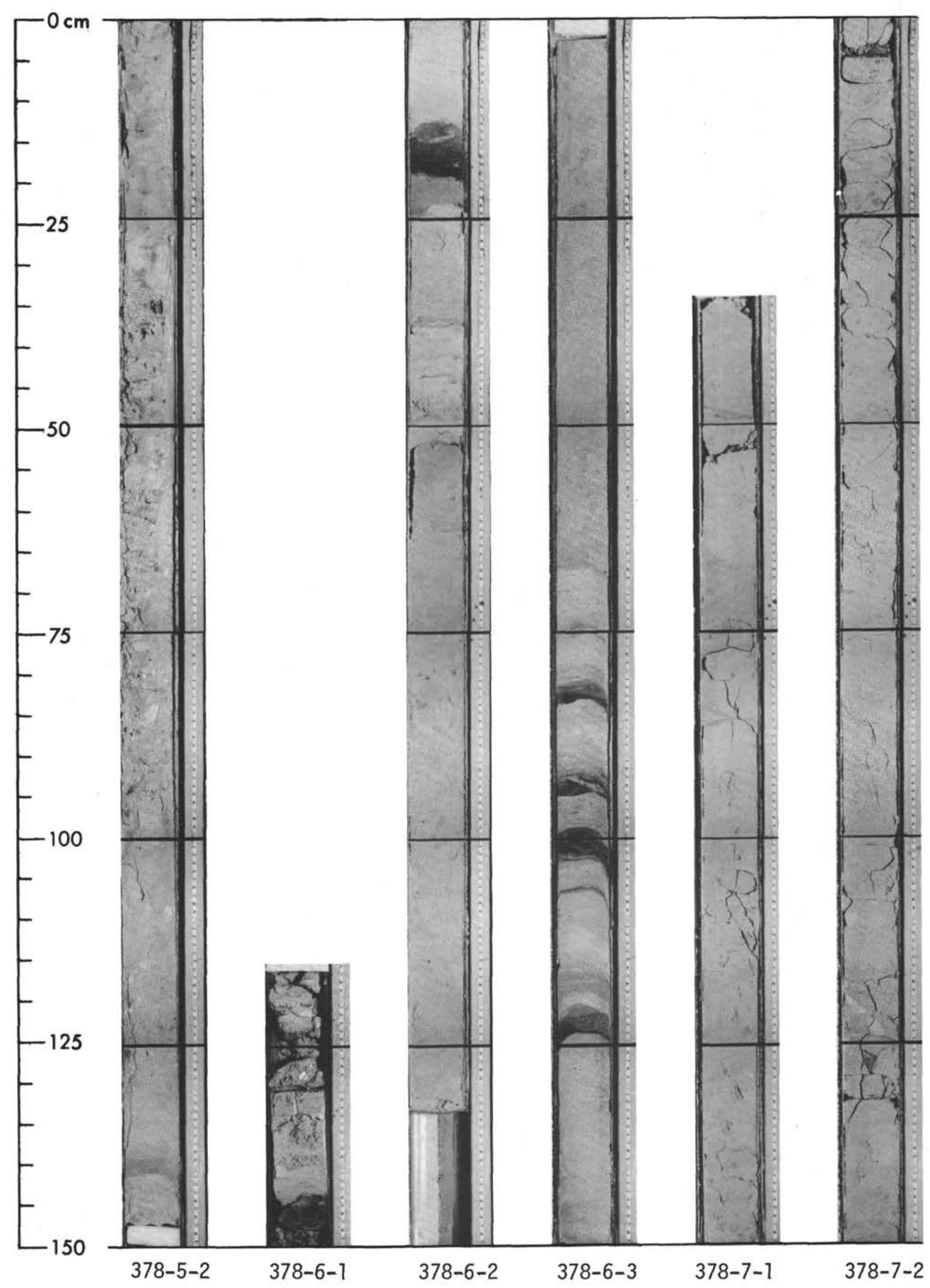




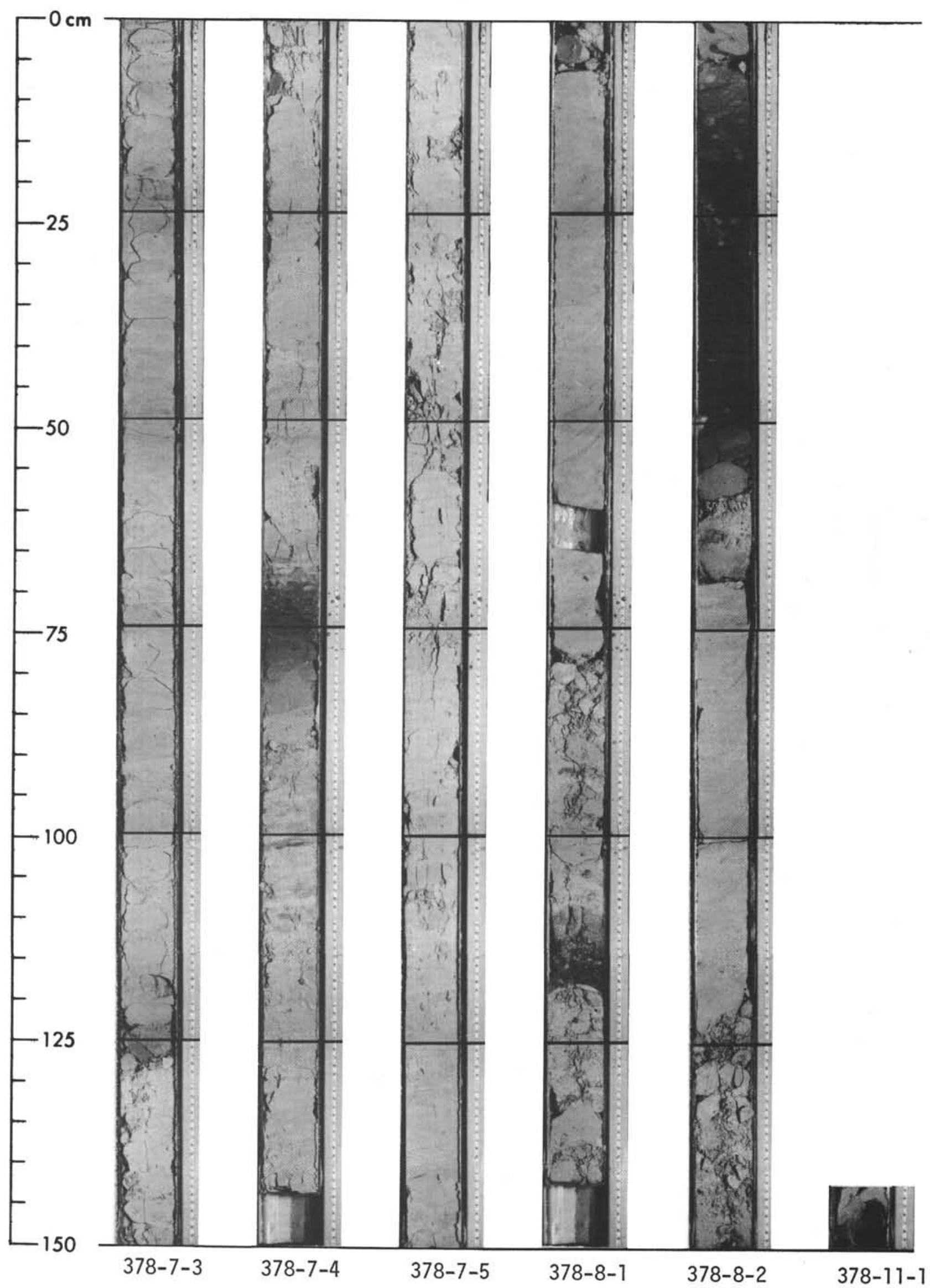




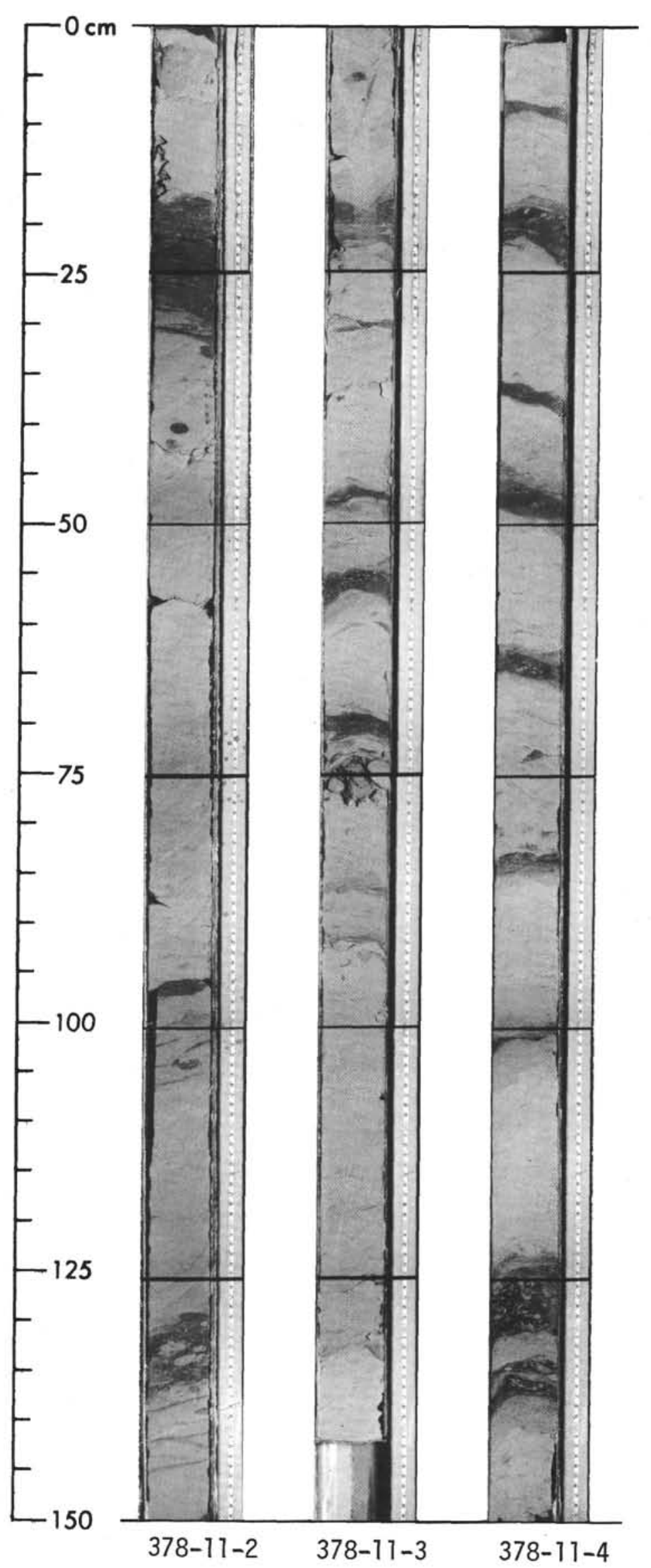




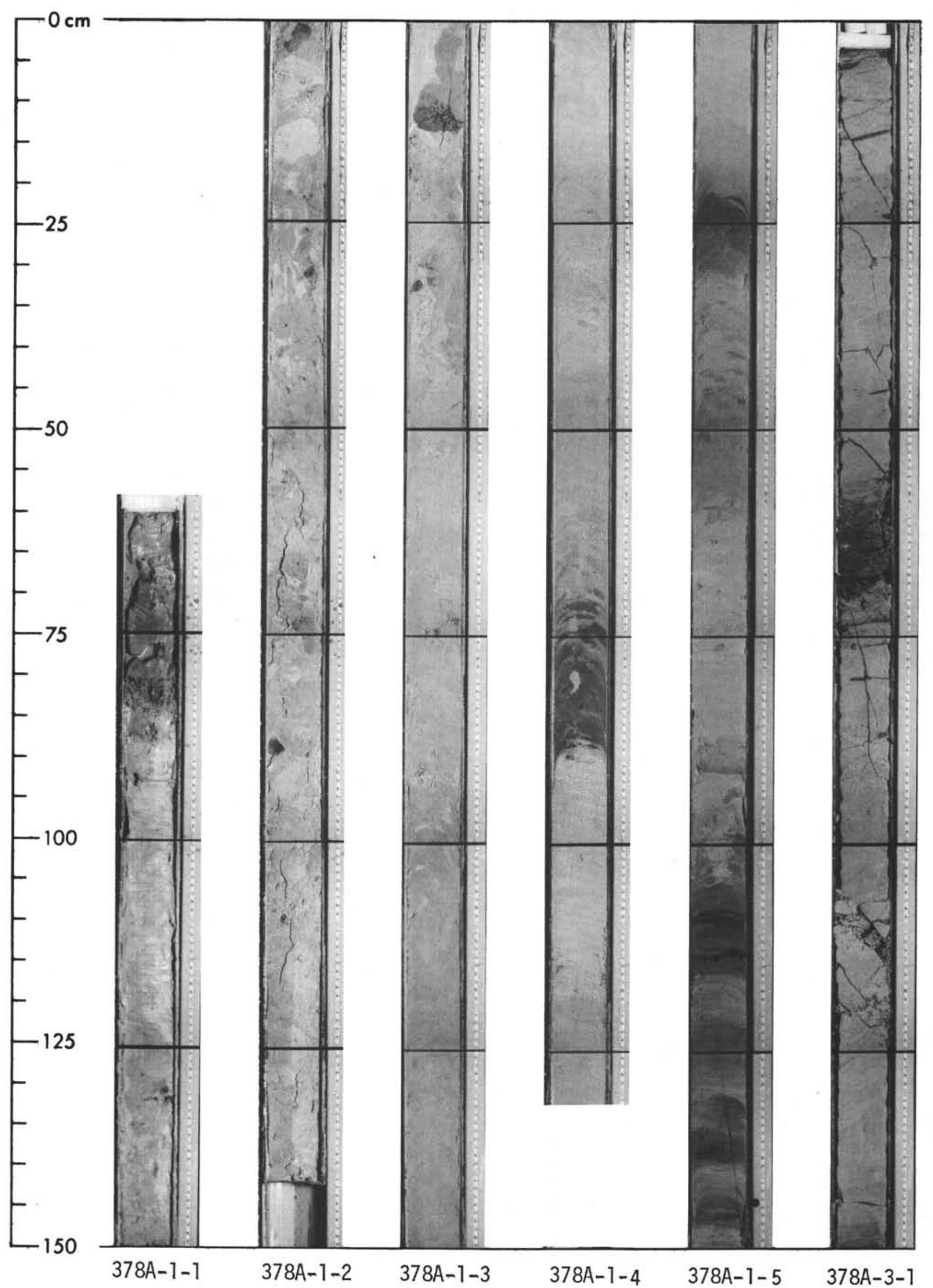




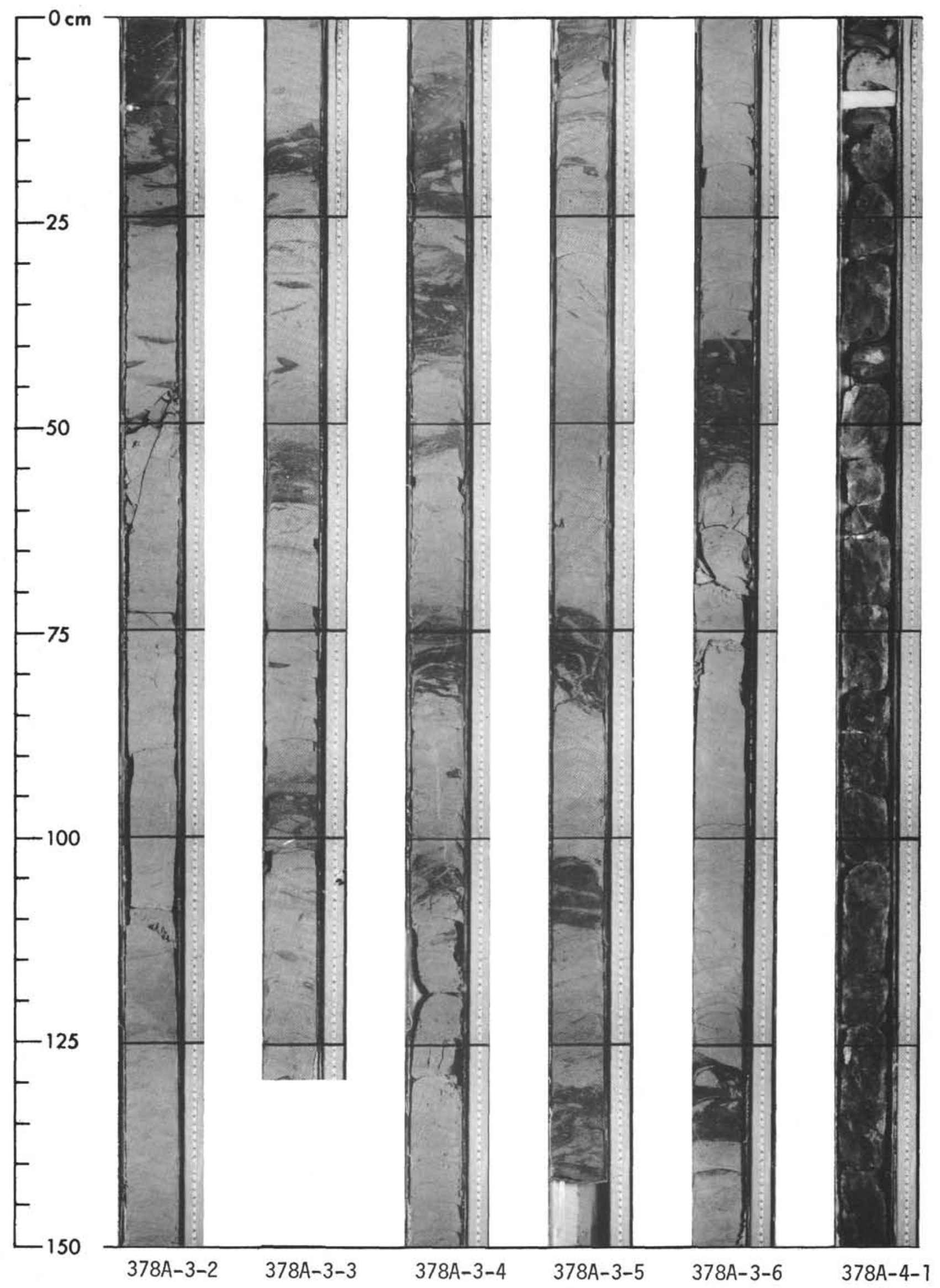




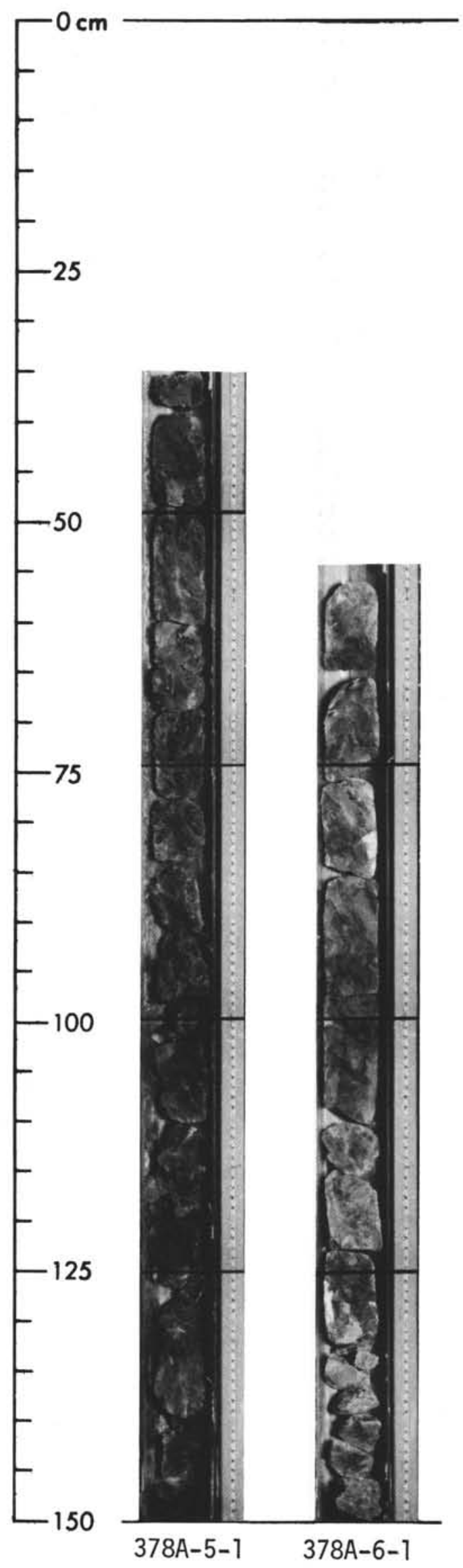

